\title{
A TAXONOMIC REVISION OF MALLOTUS SECTION MALLOTUS (EUPHORBIACEAE) IN MALESIA
}

\author{
S.E.C. SIERRA \& P.C. VAN WELZEN \\ Nationaal Herbarium Nederland, Universiteit Leiden branch, \\ P.O. Box 9514, 2300 RA Leiden, The Netherlands
}

\section{SUMMARY}

A revision of Mallotus section Mallotus in Malesia is given. Descriptions, distribution maps, habit drawings and a key to all species are provided. The diagnostic characters for the section are briefly discussed. Four species (M. barbatus, M. macrostachyus, M. mollissimus, M. paniculatus) and one variety (M. paniculatus var. formosanus) are recognised.

Key words: Euphorbiaceae, Rottlerinae, Mallotus, Malesia, taxonomy.

\section{INTRODUCTION}

Mallotus Lour. is a genus of shrubs, trees and climbers, with c. 150 species. It is classified in the subfamily Acalyphoideae, subtribe Rottlerinae (Euphorbiaceae s.s.) together with other genera (Radcliffe-Smith, 2001). The genus occurs mainly in (sub)tropical Asia, Australia and the Pacific, with only a few species in tropical Africa and Madagascar (Webster, 1994).

The large number of species in Mallotus together with the variable morphology has resulted in three main subgeneric classifications by Müller Argoviensis $(1865,1866)$, Pax \& Hoffmann (1914), and Airy Shaw (1968). In the latest classification, eight sections are recognised: Axenfeldia, Hancea, Mallotus, Oliganthae, Polyadenii, Rottlera, Rottleropsis, and Stylanthus. This article continues the revisional work on Malesian species of the separate sections of Mallotus, viz. Polyadenii (Bollendorff et al., 2000), Hancea and Stylanthus (Slik \& Van Welzen, 2001a), and Philippinenses (Sierra et al., 2005).

In the morphological phylogeny of Mallotus by Slik \& Van Welzen (2001b) it was suggested that section Mallotus is monophyletic and that Macaranga is closely related to it, but since not all of its species were included in the analysis its monophyly is not certain; the genus Mallotus differs from Macaranga in the presence of stellate and simple hairs (simple in Macaranga), alternate or opposite leaves (alternate in Macaranga), and of 2-celled anthers (4-celled in Macaranga). Until the phylogenetic studies of the genus Mallotus based on molecular and morphological data are completed we accept the traditional sectional delimitations as circumscribed by Airy Shaw (1968).

Section Mallotus was formerly known as sect. Echinus (Lour.) Pax \& K. Hoffm., but because it contained the type species (M. cochinchinensis Lour. = M. paniculatus (Lam.) 
Müll.Arg. var. paniculatus) of the genus this was invalid as an autonym is required. Airy Shaw (1968) was the first author to apply the correct name when he changed sect. Echinus into sect. Mallotus, which at the time under the ICBN of Edinburgh (Lanjouw et al., 1966) was a superfluous name; since the rule on autonomy was adopted in 1969 he should have used sect. 'Trelotra'.

In this revision we provisionally accept the sectional composition as circumscribed by Pax \& Hoffman (1914) and recognise five taxa: Mallotus barbatus Müll.Arg., M. macrostachyus (Miq.) Müll.Arg., M. mollissimus (Geiseler) Airy Shaw, M. paniculatus (Lam.) Müll.Arg. var. paniculatus, and M. paniculatus (Lam.) Müll. Arg. var. formosanus (Hayata) Hurus. These can be distinguished by a combination of several characters such as the presence of stellate hairs, and sessile, globular to disc-shaped, light yellow to orange glandular hairs on most parts; alternate leaves, subpeltate or peltate, with basal and marginal extrafloral nectaries, 3- or palminerved; dark coloured exudate in fresh twigs; bisexual or unisexual inflorescences; and hairy spines on the fruits.

Based on obvious characters, such as the presence of alternate leaves and spiny fruits, it can be inferred that the non-Malesian taxa M. apelta (Lour.) Müll.Arg., M. japonicus Müll.Arg., M. lianus Croizat, M. metcalfianus Croizat, and M. tetracoccus (Roxb.) Kurz should probably be considered part of this section.

Nomenclature follows the rules as accepted by the Botanical Congress of St. Louis (Greuter et al., 1999).

\section{MALLOTUS section MALLOTUS}

Mallotus Lour. sect. Mallotus: Airy Shaw (1968) 386, Pax \& K. Hoffm. (1914) 162. - Mallotus sect. Eumallotus Müll.Arg. (1865) 186, nom. inval. - Type: Mallotus cochinchinensis Lour. [= Mallotus paniculatus (Lam.) Müll.Arg. var. paniculatus].

Echinus Lour. (1790) 633. - Mallotus sect. Echinus Pax \& K. Hoffm. (1914) 162, nom. superfl. - Type: Echinus trisulcus Lour. [= Mallotus paniculatus (Lam.) Müll.Arg. var. paniculatus].

Rottlera Roxb. ex Willd. sect. Trelotra Baill. (1858) 425. - Type: Rottlera japonica (Thunb.) Spreng. [= M. japonicus Müll. Arg.].

Mallotus sect. Melanolepis auct. non Müll.Arg.: Müll.Arg. (1865) 184, quoad Mallotus barbatus Müll.Arg.

Rottlera Roxb. ex Willd. sect. Eurottlera auct. non Rchb.f. \& Zoll.: Rchb.f. \& Zoll. (1857) 314, quoad Rottlera zippelii Zoll. \& Moritzi, Rottlera zippelii Zoll. \& Moritzi var. minor Rchb.f. \& Zoll. (nom. nud.), Rottlera paniculata (Lam.) Blume.

Shrubs to small trees, monoecious or dioecious; branches glabrescent. Dark coloured exudate present in fresh twigs. Indumentum composed of stellate hairs, and sessile, globular to disc-shaped, light yellow to orange glandular hairs. Stipules with entire or subentire margin. Leaves alternate to apically subopposite, simple; petiole basally pulvinate; blade subpeltate or peltate, upper surface glabrescent, extrafloral nectaries basally or marginally, orbicular to elliptic, midrib, nerves and veins occasionally with glandular hairs, prominent, 3- or palminerved, nerves looping to ending in the margin, veins scalariform, veinlets reticulate. Inflorescences axillary or terminal, unisexual or bisexual; bracts 1 per node; bracteoles present or absent, both triangular to linear triangular, hairy, margin entire or subentire, apex acuminate. Flowers actinomorphic, not exceeding $1 \mathrm{~cm}$ diam.; pedicels hairy; sepals persistent, valvate, densely hairy outside, subglabrous to sparsely hairy inside, with glandular hairs on both sides, margin entire, 
apex acute; petals and disc absent. Staminate inflorescences panicles, erect, with several flowers per bract. Staminate flowers: sepals 3-5, ovate to elliptic, free, reflexed; stamens 40-90, glabrous, anthers basifixed, thecae 2, separate from each other, ovoid, opening extrorse and lengthwise, sometimes the apex with glandular hairs, connective widened, papillose; pistillode present (or absent), flattened to raised, $0.1-0.3 \mathrm{~mm}$ long, consisting of wart-like, glabrous appendices. Pistillate inflorescences racemes, panicles or spikes, becoming pendulous, with one flower per bract. Pistillate flowers: pedicels absent or present; calyx 3-5, lobes ovate, connate (on the base or almost to the apex), erect, persistent in fruits; ovary with visible spines or not, with glandular hairs, locules 3-5, 1 ovule per locule; style up to $1.5 \mathrm{~mm}$ long; stigmas narrowly triangular, plumose, densely covered with papillae above, outer surface hairy and with glandular hairs; staminodes present or absent. Fruits dehiscent capsules, surface spiny and densely hairy; wall glabrous inside. Seeds ellipsoid to globose, somewhat trigonous in transverse section; caruncle or aril absent.

Distribution - From India (W Bengal) to South China and South Japan, throughout Southeast Asia and Malesia to East Australia and West Pacific (Solomon Islands).

\section{KEY TO THE SPECIES}

1a. Domatia, if present, without a dense tuft of woolly hairs. Leaf blade not thickened near petiole insertion, rarely curved upwards. Pistillate inflorescences in racemes

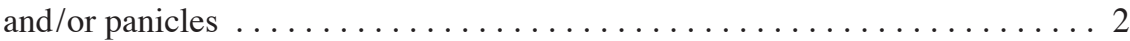

b. Domatia with a dense tuft of woolly hairs. Leaf blade thickened near petiole insertion, frequently curved upwards. Pistillate inflorescences in spikes . . . . . . . . . $\ldots \ldots \ldots \ldots \ldots \ldots \ldots \ldots \ldots \ldots \ldots \ldots \ldots \ldots \ldots$ 2. Macrostachyus

2a. Indumentum tomentose; leaf base subpeltate (up to $1.5 \mathrm{~mm}$ ), never peltate, basal extrafloral nectaries $0-2$. Pistillate inflorescences in panicles or occasionally solitary racemes. Fruit spines sparse, up to 30, exocarp visible . . 4. M. paniculatus

b. Indumentum rarely tomentose; leaf base subpeltate (up to $1.5 \mathrm{~mm}$ ) or peltate (1.6-80 $\mathrm{mm}$ ), basal extrafloral nectaries $0-4$. Pistillate inflorescences in racemes, sometimes with side branches. Fruit spines dense, more than 30, exocarp not visible. . . . 3

3a. Stipules linear triangular, $10-17$ by $0.8-1.2 \mathrm{~mm}$. Indumentum always very softfloccose, flocci up to $6 \mathrm{~mm}$ long, never tomentose. Leaves up to $80 \mathrm{~mm}$ peltate, blade $10.5-58$ by $9-45 \mathrm{~cm}$, domatia absent. Pistillate flowers sometimes with staminodes, ovary without individually visible spines. Fruit spines straight, hairs forming a continuous layer $\ldots \ldots \ldots \ldots \ldots \ldots \ldots \ldots \ldots$. $\ldots \ldots$ barbatus

b. Stipules narrowly triangular, $0.7-1.5$ by $0.1-0.3 \mathrm{~mm}$. Indumentum sometimes softfloccose, flocci up to $4 \mathrm{~mm}$ long, rarely tomentose. Leaves up to $40 \mathrm{~mm}$ peltate, blade $10-29$ by $8-25 \mathrm{~cm}$, domatia absent or present. Pistillate flowers never with staminodes, ovary with individually visible spines. Fruit spines curly, hairs not forming a continuous layer $\ldots \ldots \ldots \ldots \ldots \ldots \ldots \ldots$. M. mollissimus

\section{Mallotus barbatus Müll.Arg. - Fig. 1; Map 1}

Mallotus barbatus Müll.Arg. (1865) 184; Backer \& Bakh.f. (1964) 482; Airy Shaw (1982) 28; Corner (1988) 305; Welzen, Slik \& Bollendorff in Van Welzen et al. (2000) 97. — [Rottlera barbata Wall. (1847) no. 7822, nom. nud.; Baill. (1858) 423, nom. nud.]. - Lectotype (selected here): 
Amherst $1483=$ Wallich Numer. List $7822 C$ (holo G no. 1165; iso G no. 1164, K-W (photo in L), LE), Myanmar.

Mallotus esquirolii H. Lév. (11 Aug. 1911b) 461, non H. Lév. (10 May 1911a), (see Lauener (1983) 482). - Mallotus leveilleanus Fedde (1911) 144 ('Léveillanus'). - Mallotus leveillei Fedde ex H. Lév. (1914) 165, nom. superfl. - Type: Esquirol 120 (holo E; photo in A), China, Kweichow, Ouang-Mou.

Mallotus barbatus Müll.Arg. var. congestus F.P. Metcalf (1931) 487 ('congesta'). - Mallotus lotingensis F.P. Metcalf (1941) 206. - Lectotype (selected here): Tsiang 1131 (holo SYS; iso A, NY), China, Kwangtung, San Kai Tin.

Mallotus barbatus Müll.Arg. var. pedicellaris Croizat (1938) 135. - Type: Fang 680 (holo A), China, Szechuan, Chung-hsien.

Mallotus croizatianus F.P. Metcalf (1941) 204. - Mallotus barbatus (Wall.) Müll.Arg. var. croizatianus (F.P. Metcalf) S.M. Hwang (1985) 295. - Type: Taam 4 (holo SYS; iso A), China, Kwangsi, Pai-shou, Liang-chiang.

Mallotus luchenensis F.P. Metcalf (1941) 206. - Type: Ching 5699 (holo SYS; iso A, NY), China, Kwangsi, Shan Fang, N. Luchen.

Mallotus barbatus Müll. Arg. var. hubeiensis S.M. Hwang (1985) 296. - Type: Li 7620 (holo SCIB n.v.), China, Hubei.

Mallotus barbatus Müll.Arg. var. wui H.S. Kiu (2003) 99. - Type: Exped. Yue 74-4586 (holo SCIB n.v.), China, Guandong, Fengkai, Qixing.

Shrubs to small trees up to $12 \mathrm{~m}$ high, dbh up to $15 \mathrm{~cm}$, monoecious or dioecious. Outer bark finely striate, smooth, up to $6 \mathrm{~mm}$ thick, greyish with patches of brown, on cross section reddish brown; sapwood straw coloured with pinkish brown streaking. Indumentum densely hairy, very soft-floccose, flocci up to $6 \mathrm{~mm}$ long. Stipules linear-triangular, $10-17$ by $0.8-1.2 \mathrm{~mm}$, persistent, margin subentire, apex acuminate. Leaves: petiole $3-40$ by $2-7 \mathrm{~mm}$, blade peltate for $10-80 \mathrm{~mm}$, broadly ovate to ovate, $10.5-58$ by $9-45 \mathrm{~cm}$, length/width ratio $1-1.3$, base truncate, rounded or obtuse, margin dentate, sometimes 2-lobed at widest part of blade, longest lobes up to $50 \mathrm{~mm}$, upper surface pinkish red when young, dull green when old, basally with $0-4$ extrafloral nectaries, $1.2-4.5$ by $0.7-2 \mathrm{~mm}$, marginal nectaries $0-9$ per side, $2-6(-18) \mathrm{mm}$ from margin, $0.7-1$ by $0.5-1 \mathrm{~mm}$, lower surface brownish green, palminerved, nerves $7-11$ per side, mostly ending in the margin. Inflorescences terminal, unisexual or bisexual, axes greenish tawny, basally $2-5 \mathrm{~mm}$ thick; bracts $5-20$ by c. $1 \mathrm{~mm}$, bracteoles linear triangular $2.7-4.3$ by $0.4-0.6 \mathrm{~mm}$, persistent, margin subentire. Staminate inflorescences up to $65 \mathrm{~cm}$ long, side branches up to $30 \mathrm{~cm}$ long, with 2 or 3 flowers per node, nodes per branch up to 130. Staminate flowers 6-9 mm diam.; pedicels 3-5.5 mm long; sepals 4 or $5,3-5$ by $1.3-3 \mathrm{~mm}$, pale light cream to tan cream; stamens $60-85$, pale light green to yellow, filaments $1-4 \mathrm{~mm}$ long, anthers $0.3-0.4$ by $0.2-0.3 \mathrm{~mm}$, pale light yellow; pistillode absent (stamens absent from middle of flower, centre sometimes with reduced wart-like appendices). Pistillate inflorescences racemes, up to $55 \mathrm{~cm}$ long, occasionally with side branches, up to $10 \mathrm{~cm}$ long, nodes up to 80. Pistillate flowers 4-6 mm diam.; pedicels 1-45 mm long; calyx (3-) or 4- or 5- or (6-)lobed, connate on the base, $2.5-5 \mathrm{~mm}$ long, lobes $2-3$ by $1.5-2.5 \mathrm{~mm}$; ovary $3(-5)$-locular, $2.5-3.5$ by $2.2-3 \mathrm{~mm}$, spines not individually visible; style up to $1.5 \mathrm{~mm}$ long; stigmas $2-6 \mathrm{~mm}$ long, yellow; staminodes sometimes present, also persistent in fruits. Fruit 10-21 by 14-20 mm, with strong smell, yellow with reddish touch, spines numerous, straight, thin, less hairy, up to $7 \mathrm{~mm}$ long, hairs forming a continuous layer, rubbing off; column $7-9$ by $1-1.5 \mathrm{~mm}$. Seeds ellipsoid, $4.8-5.5$ by $3-4.5$ by $2-4 \mathrm{~mm}$, surface smooth, black; hilum c. 1 by c. $1.3 \mathrm{~mm}$. 


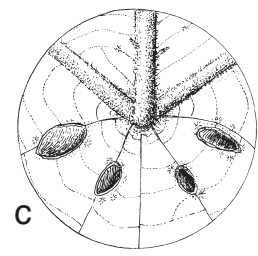

b
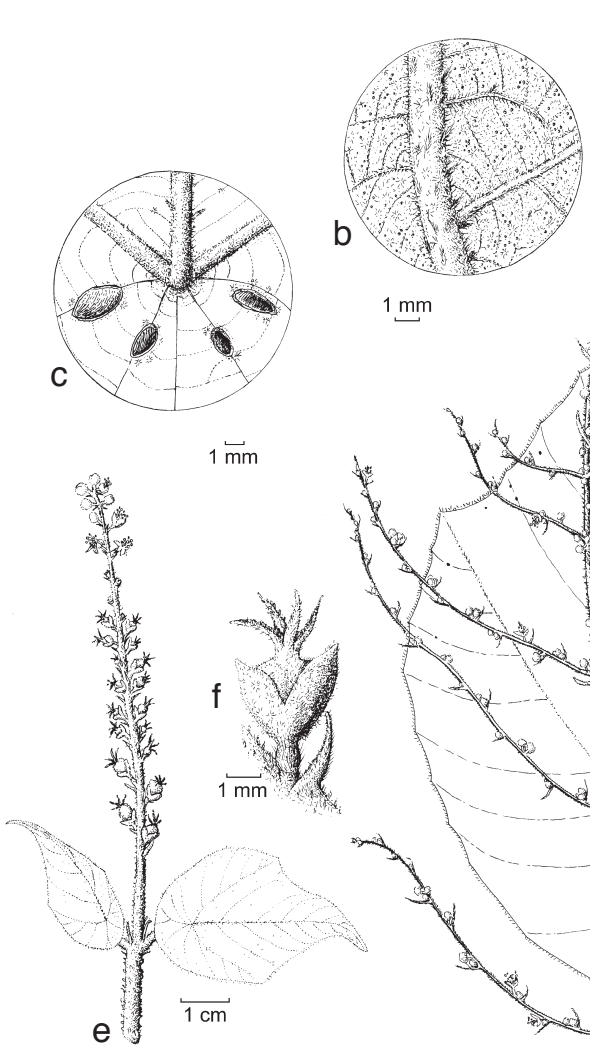

$$
1 \mathrm{~mm}
$$
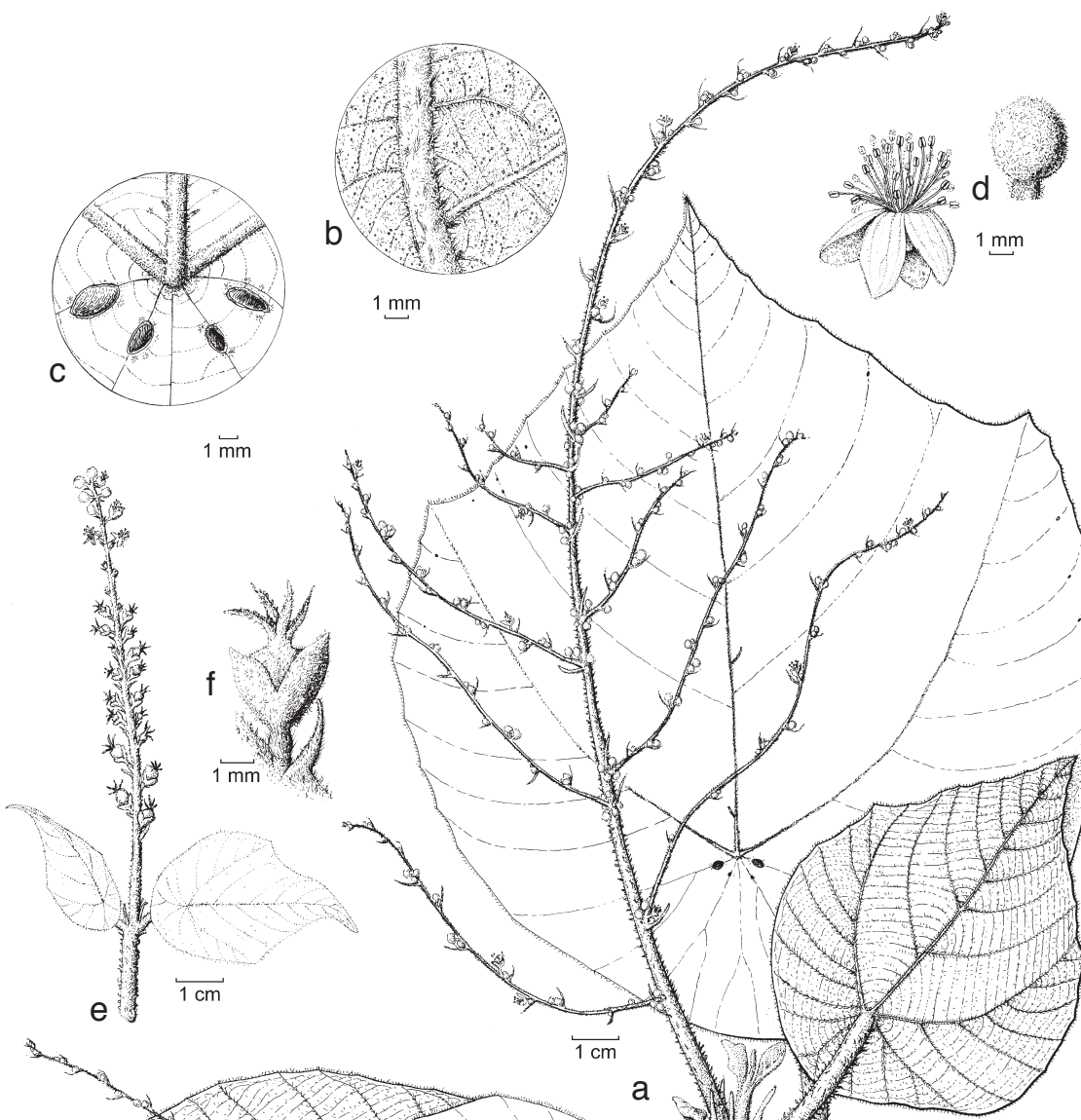

a
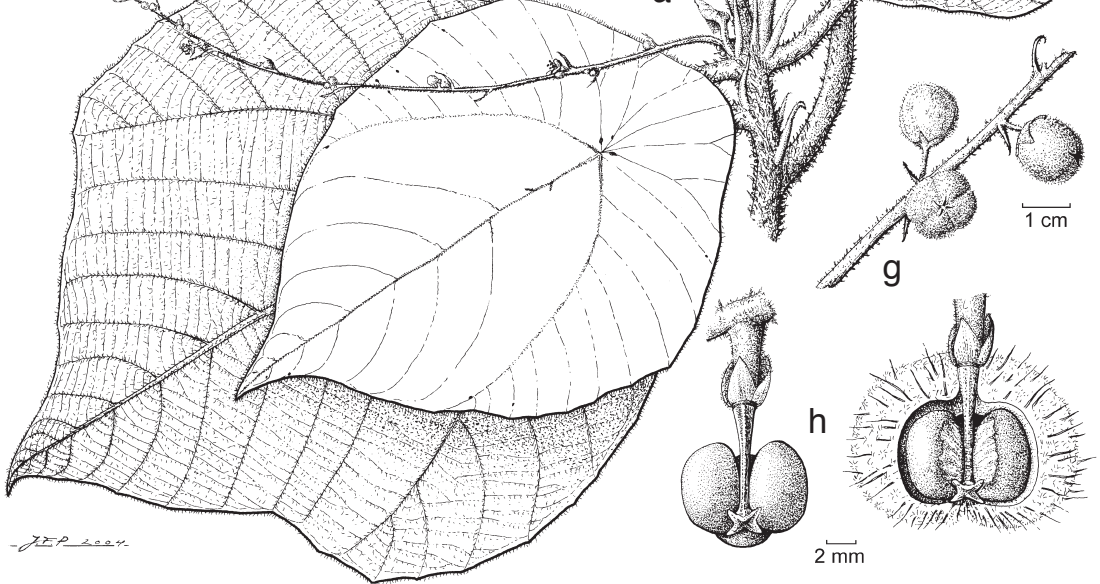

Fig. 1. Mallotus barbatus Müll.Arg. a. Habit with male inflorescence; b. detail of leaf lower surface with glandular hairs; c. base of leaf upper surface with extrafloral nectaries; d. staminate flower and bud; e. pistillate inflorescence; f. pistillate flower; g. immature fruits; h. dehisced fruit showing seeds and column (a, d: Garrett 760; b, c, g, h: Geesink et al. 5653; e, f: Put 1618; all L). 


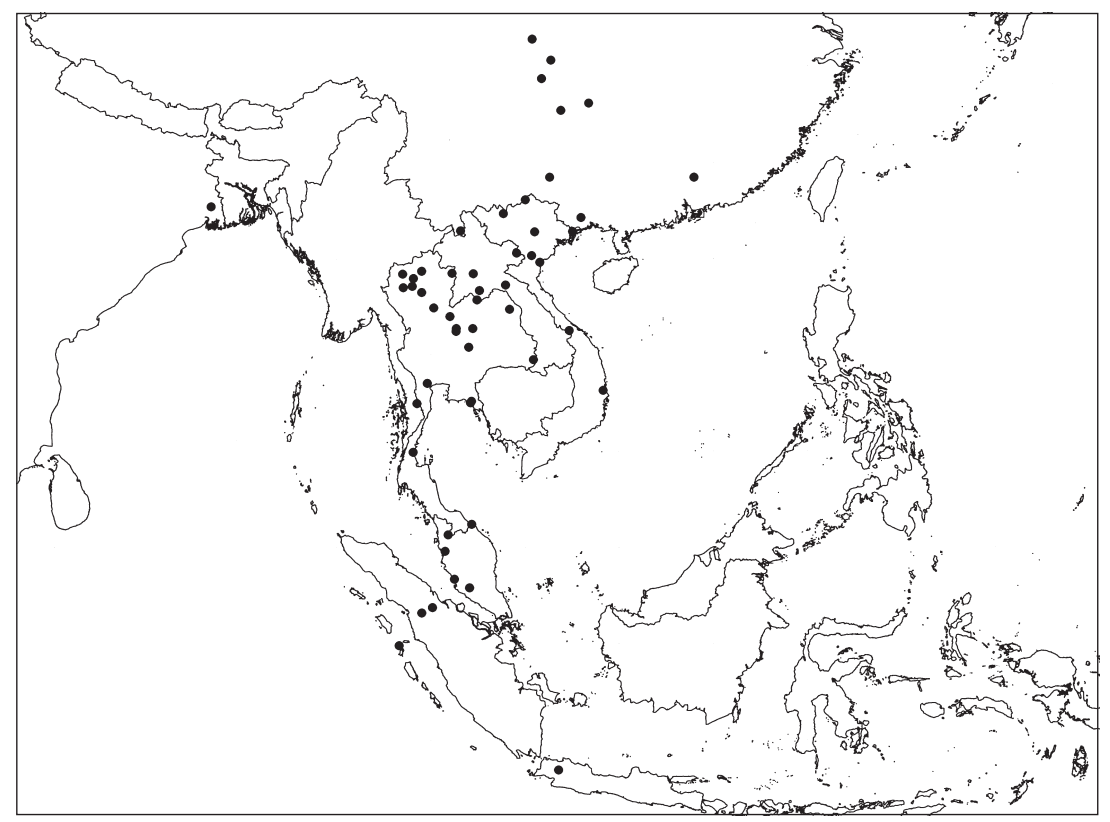

Map 1. Distribution of Mallotus barbatus Müll.Arg.

Distribution - From India (W Bengal) to South China, Southeast Asia mainland, Malay Peninsula, Sumatra, and Java.

Habitat \& Ecology - Locally common in deciduous and evergreen forest, mostly in open, often very disturbed or burned places, along road and river sides; on a large variety of soil types, like shale, limestone, sandstone, and sandy clay. Altitude: sea level up to $1400 \mathrm{~m}$. Flowering and fruiting the whole year through.

Uses - The roots and fruits are used against muscle stiffness. The seeds yield a fatty oil used for making candles.

Vernacular names - Laos: Dtong dtah waen (Lao). Malay Peninsula: Baleh anging, ba-le-a-nging, balek angin, balik angin, tampun (Malay). Thailand: tawng-yow (Lao); hu chang, kalo khon, kalo yai thai, khi thao, krakok khon, mueat tao, po hun, po tao, salapang, salapang bai yai, sa-po-sa, tao khon, tao tep; tong tao, ya khi thut (Thai); siamese pom-pom tree (English). Vietnam: Cay co nhum. Partly after Smitinand (2001).

\section{Mallotus macrostachyus (Miq.) Müll.Arg. - Fig. 2; Map 2}

Mallotus macrostachyus (Miq.) Müll. Arg. (1866) 963; Airy Shaw (1975) 165; Corner (1988) 306; Welzen, Slik \& Bollendorff in Van Welzen et al. (2000) 101. - Rottlera macrostachya Miq. (1860) 454. - Lectotype (selected here): Teijsmann HB 3245 (U), Indonesia, Sumatra.

Mallotus insignis Müll.Arg. (1865) 193; (1866) 975. - Type: Schomburgk 52 (holo K), Singapore. Mallotus albus auct. non (Roxb.) Müll. Arg.: Müll.Arg. (1865) 188, quoad Motley 530 (CGE, K), Indonesia, Borneo; Wallich Numer. List 7820 (K-W mixed), Malay Peninsula, Penang.

Mallotus barbatus auct. non Müll.Arg.: Müll.Arg. (1865) 184, quoad Wallich Numer. List 7820 (K-W mixed), Malay Peninsula, Penang. 
Shrubs to small trees up to $16 \mathrm{~m}$ high, dbh up to $25 \mathrm{~cm}$, dioecious, occasionally monoecious. Crown spreading, flat; outer bark finely fissured, soft, brownish grey, inner bark fibrous inwards, yellowish green, cambium yellow, sapwood white. Indumentum tomentose to puberulent. Stipules triangular, $2.8-7$ by $1-1.8 \mathrm{~mm}$, persistent, margin entire, apex acute. Leaves: petiole $2-36$ by $1-4 \mathrm{~mm}$; blade subpeltate for $1.5 \mathrm{~mm}$, peltation near petiole insertion often thick and frequently curved upwards, broadly ovate to ovate, $9.2-31$ by $7.8-25 \mathrm{~cm}$, length / width ratio $1-1.3$, base truncate, rounded, to slightly cuneate, margin dentate, or serrate, rarely shallowly 2-lobed at widest part of blade, upper surface dark green, basally with $0-2$ extrafloral nectaries, $1.3-3$ by 0.5-2.5 mm, marginal nectaries $0-9$ per side, $1.5-10 \mathrm{~mm}$ from margin, $0.6-1$ by 0.6-8 mm, lower surface brownish grey, domatia with a dense tuft of woolly hairs, 3-nerved, nerves 7 or 8 per side, mostly ending in the margin. Inflorescences axillary or terminal, unisexual or bisexual, axes light brownish, basally $2-4 \mathrm{~mm}$ thick; bracts triangular, $1-2.5$ by $0.6-10 \mathrm{~mm}$, persistent, margin entire, bracteoles absent. Staminate inflorescences up to $112 \mathrm{~cm}$ long, side branches up to $65 \mathrm{~cm}$ long, with 1 or 2 flowers per node, nodes per branch up to 120 . Staminate flowers $4-4.5 \mathrm{~mm}$ diam., fragrant; pedicels $3.2-4.2 \mathrm{~mm}$ long; sepals 3 or $4,2-2.7$ by $1.2-1.7 \mathrm{~mm}$; stamens $60-90$, filaments $1-3 \mathrm{~mm}$ long, white, anthers $0.3-0.35$ by $0.2-0.25 \mathrm{~mm}$, light yellow; pistillode present. Pistillate inflorescences spikes, up to $80 \mathrm{~cm}$ long, seldomly with side branches (up to $14 \mathrm{~cm}$ long), nodes up to 150 (see note 1). Pistillate flowers 3-7 $\mathrm{mm}$ diam., sessile; calyx 4- or 5-lobed, connate almost to the apex, 3-5 mm long, lobes $0.5-1.7$ by $0.8-1.5 \mathrm{~mm}$, light brownish; ovary 3 -locular, $3.2-4$ by $1.8-2.2 \mathrm{~mm}$, spines individually not visible, style up to $1.2 \mathrm{~mm}$ long; stigmas 4-5 $\mathrm{mm}$ long, dark brown; staminodes absent. Fruits $11-16$ by $10-14 \mathrm{~mm}$, light green with brown tomentum, spines numerous, straight, thin, less hairy, up to $4 \mathrm{~mm}$ long, hairs forming a continuous

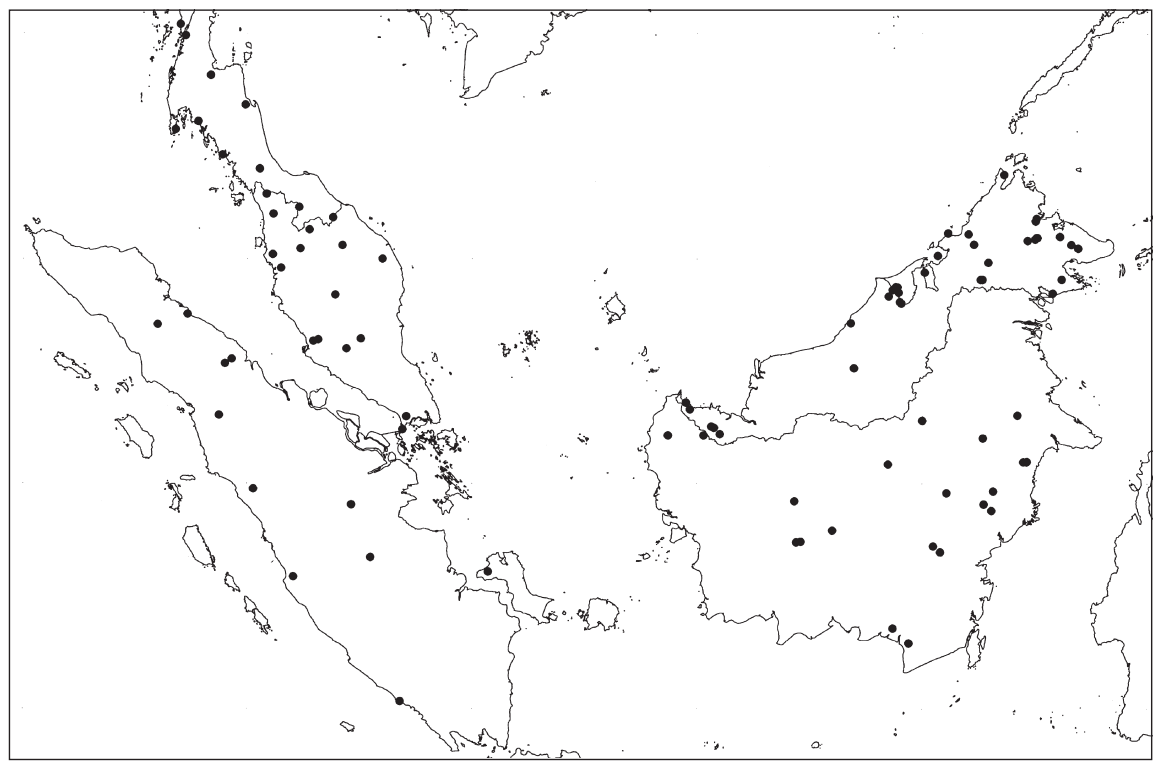

Map 2. Distribution of Mallotus macrostachyus (Miq.) Müll.Arg. 


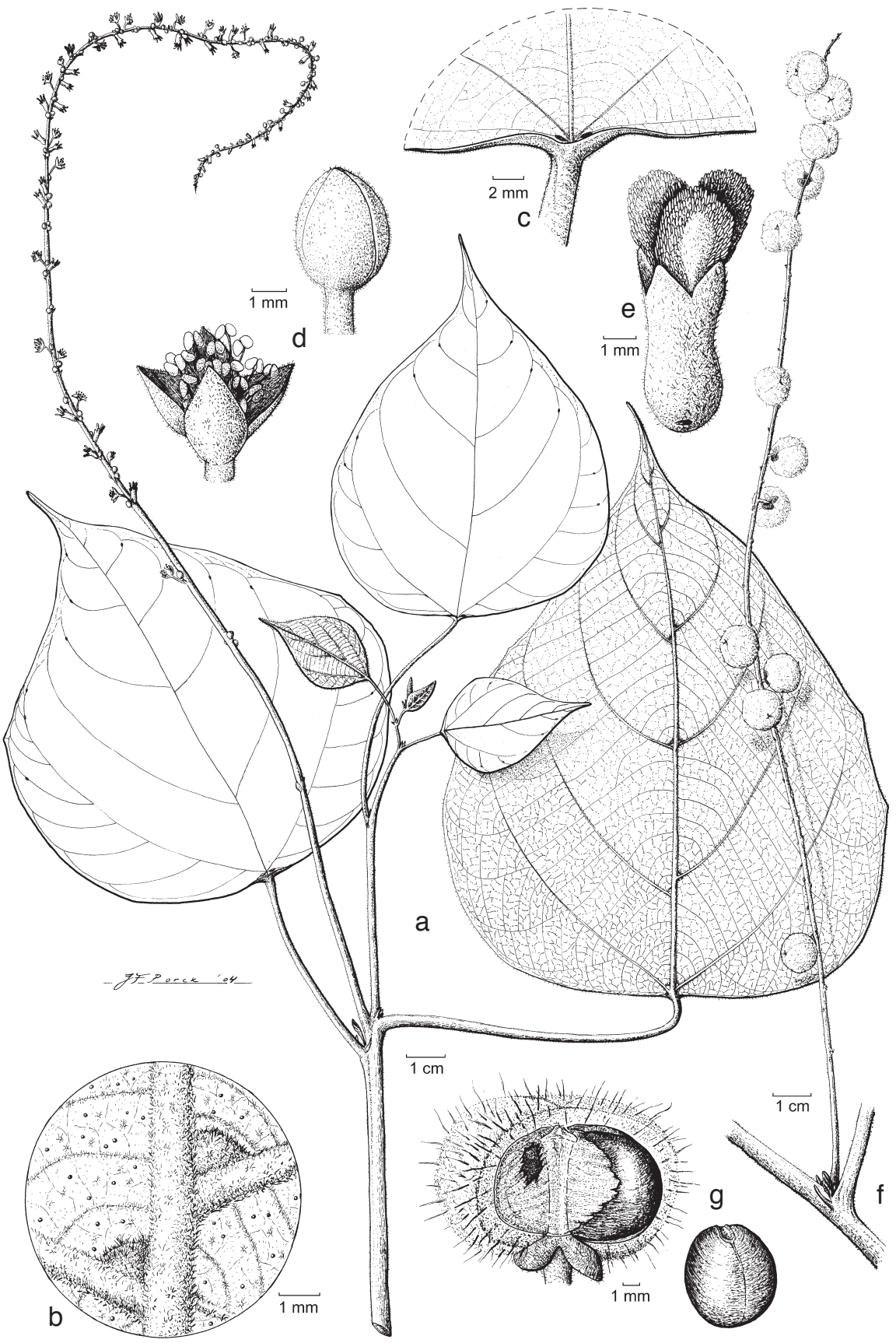

Fig. 2. Mallotus macrostachyus (Miq.) Müll. Arg. a. Habit with bisexual inflorescence; b. detail of leaf lower surface with glandular hairs and domatia; c. base of leaf upper surface with extrafloral nectaries; d. staminate flower and bud; e. pistillate flower; f. infructescence; g. dehisced fruit showing seeds and column (a-e: Davies \& Unam 97009; f, g: Shimizu et al. T-27167; all L). 
layer, rubbing off; column $5-6$ by $1.2-2 \mathrm{~mm}$. Seeds ellipsoid, $4-5$ by $4-4.5$ by $3.5-4$ $\mathrm{mm}$, surface irregular, dark brown; hilum $2.3-2.5$ by $1.8-2 \mathrm{~mm}$.

Distribution - Thailand to Singapore, Sumatra, and Borneo.

Habitat \& Ecology - Locally common in deciduous and evergreen forest, mostly in open, often very disturbed or burned places, along road and river sides, swampy areas; on a large variety of soil types, like shale, limestone, sand, and basalt. Altitude: sea level up to $800 \mathrm{~m}$. Flowering and fruiting the whole year through. The male flowers are visited by Trigona bees.

Uses - The leaves are used as an antidote against snake-poison. The wood is used as firewood.

Vernacular names - Thailand: fame, fami, lo, lo khon, lua, plao thong, plao-yai (Thai); common pom-pom tree (English). Malay Peninsula: Selau, balek angin. Singapore: Balek angin. Sumatra: Baliek anggien, batang balik; pedau-pedau (Dusun); si tarak balanggingan. Indonesia (Borneo): Kapit mawat (Kenyah), kayu balik angin, kayu kapit, buah beliangin, kajoe si tarak balanggingan. Sabah: Dahau (K'zan K'gan); dahu (Dusun/Bundu Tuhan); dauah (Dusun Putatan); mangabong, ngoludon, padauh-padau (Dusun); tondon tondon (Suluk). Sarawak: Balek angin; entupak, kelempah pinggai, kelipak pinggai, kerimpah pinggai (Iban). Brunei: Lekon abai, lokon (Dusun); entupak, nentupak (Iban). Partly after Smitinand (2001).

Note - BS 2576 has aberrant female inflorescences, probably infected by a virus.

\section{Mallotus mollissimus (Geiseler) Airy Shaw - Fig. 3; Map 3}

Mallotus mollissimus (Geiseler) Airy Shaw (1972) 297; Backer \& Bakh.f. (1964) 482; Airy Shaw (1975) 165; (1980) 168; (1981) 326; (1982) 28; (1983) 37; P.I. Forst. (1999) 473, 494; Keßler (2002) 49; Welzen, Slik \& Bollendorff in Van Welzen et al. (2000) 102. - Croton mollissimus Geiseler (March 1807) 73. - Chrozophora mollissima (Geiseler) A. Juss. ex Spreng. (1826) 851. - Echinus mollissimus (Geiseler) Baill. (1866) 316. - Type: Herb. Vahl s.n. (holo C; photo at A), China, see note 1.

Croton ricinoides Pers. (Sept. 1807) 586. - Rottlera ricinoides (Pers.) A. Juss. (1824) 111, t. 9, f. 29A. - Mallotus ricinoides (Pers.) Müll.Arg. (1865) 187, nom. superfl. - Lectotype (Forster, 1999): Lahaye s.n. (holo P, Herb. A. Juss. 16578, [IDC microfiche no. 6206]), India, see note 2.

Adisca zippelii Blume (1826) 611. - Adisa zippelii Steud. (1840) 28, sphalm. - Rottlera zippelii Hassk. (1844) 238. - Mappa zippelii Zoll. \& Moritzi ex Moritzi (1846) 17. - Mallotus zippelii F. Muell. (1864) 139. - Lectotype (selected here): Blume s.n. (holo L barcode 0294214; iso L barcode 0294172), Java, Mt Salak.

Adelia bernardia auct. non L.: Blanco (1837) 814; Merr. (1918) 221. - Adelia barbata Blanco (1845) 561. - Neotype (selected here): Merrill Species Blancoanae 474 (holo US; iso K, L), Philippines, Luzon, Rizal.

Mallotus pycnostachys F. Muell. (1864) 138. - Lectotype (Forster, 1999): MEL 232430, 32-34, Australia, Queensland, North Kennedy Distr., Mt Elliott.

Mallotus barbatus auct. non Müll.Arg.: Merr. (1912) 397. - Mallotus confusus Merr. (1920) 559. - Type: BS (Ramos \& Edaño) 29153 (holo PNH†; iso A, P, US), Philippines, Luzon, Tabayas Province, Mt Tulaog.

[Mappa sp.: Moritzi (1846) 17]. - Rottlera zippelii Zoll. \& Moritzi var. minor Rchb.f. \& Zoll. (1857) 315, nom. nud. - Rottlera peltata auct. non Roxb.: Miq. (1859) 395. - Voucher: Zollinger 319 $(\mathrm{G}, \mathrm{L})$, Indonesia, Java.

Shrubs to small trees up to $12 \mathrm{~m}$ high, dbh up to $15 \mathrm{~cm}$, dioecious, occasionally monoecious. Bole up to $5 \mathrm{~m}$ high; crown up to $6 \mathrm{~m}$ long; outer bark rough to finely fissured or pustular lenticellate, up to $2 \mathrm{~mm}$ thick, yellowish green, under surface light reddish 


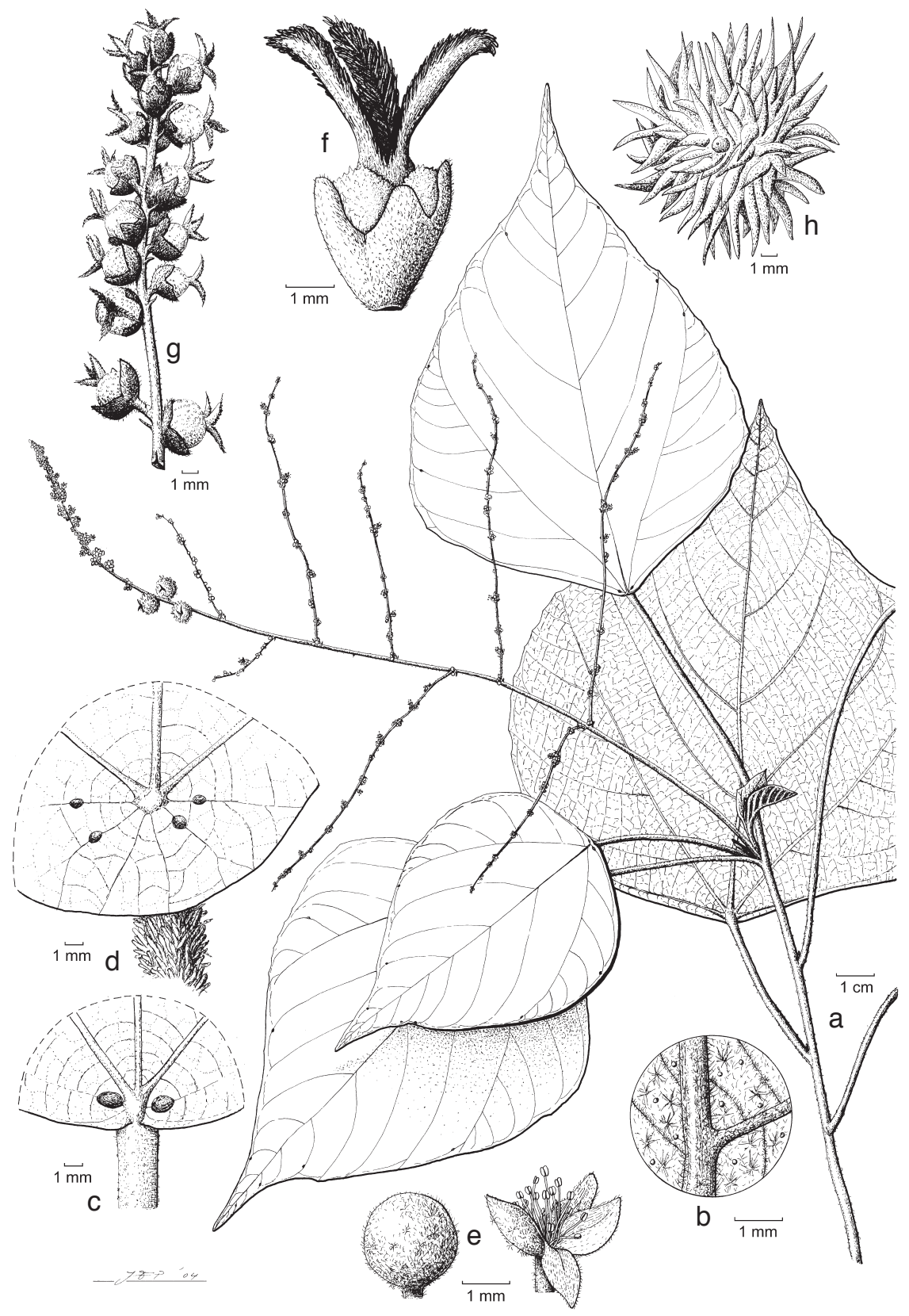

Fig. 3. Mallotus mollissimus (Geiseler) Airy Shaw. a. Habit with bisexual inflorescence; b. detail of leaf lower surface with glandular hairs; $c$. base of leaf upper surface with 2 extrafloral nectaries; d. peltate leaf upper surface with 4 extrafloral nectaries and floccose indumentum; e. staminate flower and bud; f. pistillate flower; g. young infructescence; h. fruit (a: University of San Carlos 883; b: University of San Carlos 839; c: Santos 4769; d: PNH 36026 (Frake); e: PNH 1613 (Alcasid); f, g: PNH 11282 (Edaño); h: Santos 5302; all L). 
brown; inner bark up to $6 \mathrm{~mm}$ thick, fibrous, light greenish; sapwood cream with watery sap; wood medium hard, cream. Indumentum dense, sometimes soft-floccose, flocci up to $4 \mathrm{~mm}$ long, rarely tomentose. Stipules narrowly triangular, $0.7-1.5$ by $0.1-0.3$ $\mathrm{mm}$, caducous to persistent, margin subentire, apex acuminate. Leaves: petiole 30-200 by $1.5-4 \mathrm{~mm}$; blade subpeltate or peltate for $1.5-40 \mathrm{~mm}$, ovate, $10-35$ by $8-30 \mathrm{~cm}$, length/width ratio 1.2-1.4, reddish brown when young, base truncate to cuneate, margin entire to dentate, seldom 2-lobed at the widest part of the blade, longest lobes up to 15 mm long, upper surface green, basally with $0-2(-4)$ extrafloral nectaries, $0.8-4$ by $0.4-1.8 \mathrm{~mm}$, marginal nectaries $0-15$ per side, $2-10 \mathrm{~mm}$ from margin, $0.5-1$ by $0.5-1$ $\mathrm{mm}$, lower surface greenish grey to brownish, with domatia or not; 3 - or palminerved, nerves 8-11 per side, mostly ending in the margin. Inflorescences axillary or terminal, unisexual or bisexual, axes greenish tawny, basally 1-4 mm thick; bracts narrowly triangular, $1.8-3$ by $0.2-0.5 \mathrm{~mm}$, caducous to persistent, margin subentire; bracteoles absent. Staminate inflorescences up to $43 \mathrm{~cm}$ long, side branches up to $20 \mathrm{~cm}$ long, with 3-5 flowers per node, nodes per branch up to 100. Staminate flowers 3-5 mm diam.; pedicels $3-3.5 \mathrm{~mm}$ long; sepals 3 or 4, elliptic, $2-3$ by $1.5-2 \mathrm{~mm}$, greyish; stamens $50-80$, yellowish, filaments $1.5-3 \mathrm{~mm}$ long, anthers $0.2-0.3$ by $0.1-0.2 \mathrm{~mm}$; pistillode present. Pistillate inflorescences racemes, up to $35 \mathrm{~cm}$ long, occasionally side branches up to $13 \mathrm{~cm}$ long, nodes up to 130 ; bracts caducous to persistent. Pistillate flowers 3-4 mm diam.; pedicels up to $0.5 \mathrm{~mm}$ long; calyx 3-5-lobed, connate on the base, $2-3 \mathrm{~mm}$ long, green with brown indumentum, lobes ovate, $1.5-2$ by $1-1.7 \mathrm{~mm}$; ovary 3-locular, $2.2-3$ by $2-3 \mathrm{~mm}$, spines individually visible; style up to $1.2 \mathrm{~mm}$ long; stigmas 2.2-2.8 mm long, greenish yellow; staminodes absent. Fruits $10-16$ by 11-17 mm, greenish brown, smelling strong when dried, see note 3 , spines numerous, curly, thin, less hairy, up to $7 \mathrm{~mm}$ long, hairs not forming a continuous layer, easily rubbing off; column $5-6$ by $1-1.8 \mathrm{~mm}$. Seeds ellipsoid, $4-5$ by $3.8-4$ by $3-3.2 \mathrm{~mm}$, smooth, black, shiny; hilum c. 1 by $0.6-0.7 \mathrm{~mm}$.

Distribution - From Sumatra to East Australia and West Pacific (Solomon Islands).

Habitat \& Ecology - Locally common in deciduous and evergreen forest, mostly in open, often very disturbed or burned places, gallery forest, mangrove edges, swamp forest, riparian vegetation, notophyll vineforest, on mountain slopes, open grasslands and along hill and road sides; on a large variety of soil types, like alluvial, basalt rocks, clay, coral limestone, loam, rocky, sandy, ultrabasic, and volcanic. Altitude: sea level up to $1700 \mathrm{~m}$. Flowering and fruiting the whole year through. Observed to be visited by small brown ants.

Uses - The roots are used against headaches and malaria. The inner bark is used as a strap for carrying and for sing sing decorations. The leaves are used as food covering, against stomach cramp, and together with the bark used to cure the spleen. The wood is used for making scabbards, ritual spears, building construction, and as firewood.

Vernacular names - Sumatra: Kajoe si balihangin. Java: Djalikangin, toetoep beling. Sabah: dapulan, dul-long perampuang (Bajau); patau jantan (Bajec); kasobong (Daho); andalamit, angkut angkut, dahu, dau, kedayan, lukabang, padau-padau, padahu, pandau pandu (Dusun); laba-laba (Kinabatangan); bajau papar, murut tenom (Kwijau); ambutan, dawoh, dusun, lapakon, (Murut); dapulon-dapulon, pais tahun (Suluk); apat retu, apatmaratu, pit dau (Sungei); andalasan, kehat, labah-labah, labah lahat, ludai, padauk, 


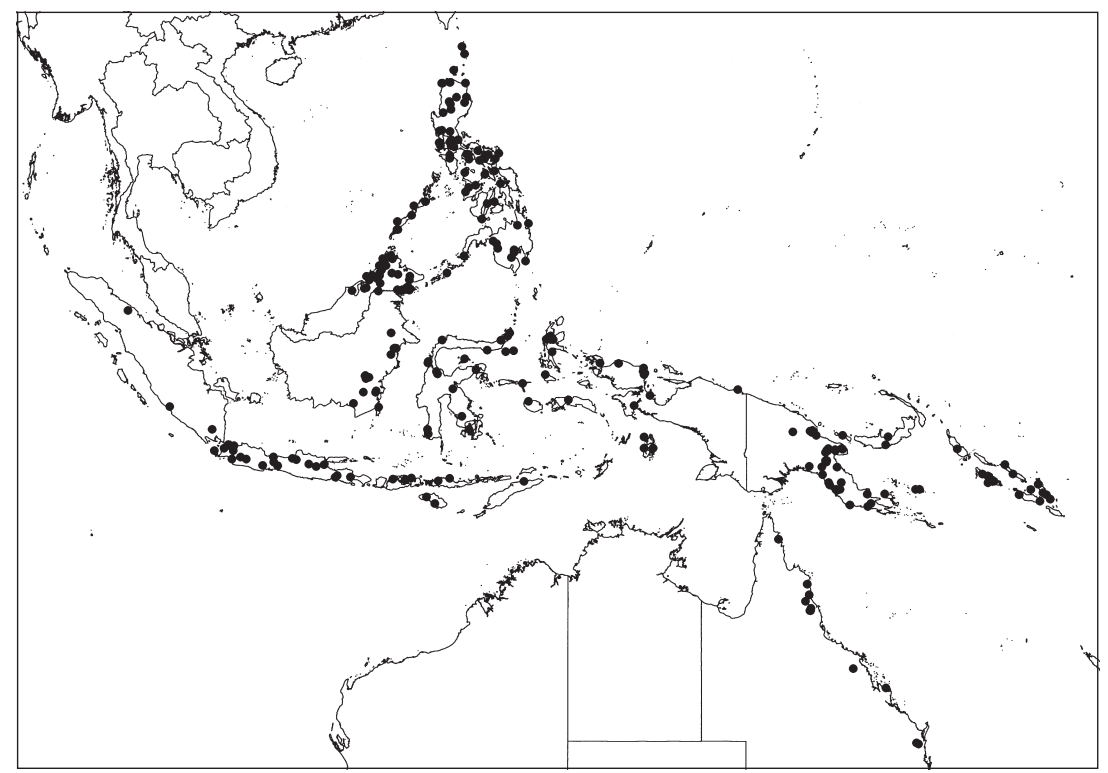

Map 3. Distribution of Mallotus mollissimus (Geiseler) Airy Shaw.

porak sembelik, purak sambalik. Sarawak: Labah-labah (Kedayan); lalapakon (Murut). Brunei: jabai, laba-laba, markubong, prestaang, toka toka, tuka, sawar bubu. Philippines: hanonomo (Bisáya); indang (Lánao); bampalan (Súlu); hinlaumo (Tagálog); ipalan (Yakán); aab-ben, anumoh, anumú tagabas, atay-atay, baray, cahoy-dalaga, gapas gapas, malang-malang, maracapau, tagaan. Sulawesi: Kayou wollo sola, laransiana oeroene, lemoro, ota-ota. Papua (Irian Jaya): Bekoeaap, bekwaap, bie grai, majetrip (Hattam); mangafafin (Biak). Papua New Guinea: Atatiza (Garaina, Waria); majetrip (Hattam); wapi (Marok); siripupo (Orakiva); wasittatt (Wein); ah papper, goreh-gobu, hukoitiiti, hukopu, kikikanauant, la putu la basi, moraka, ongohn, tiwotiwo, ukoiitiiti. Solomon Islands: A'rafu, airafu, airahu, albuis, suamango, suamangokwao, suamangongwane (Kwara'ae); hohoe, tukituki hohoe.

Notes - 1. Forster (1999) states that Müller Argoviensis (1866; 964 sub. M. ricinoides) mentioned a Staunton collection from China as the type of M. mollissimus. But actually Müller Argoviensis indicated two specimens from China: a Staunton collection in herbarium $\mathrm{G}$ and a Vahl collection in herbarium C. Part of the confusion has arisen because when reading Müller Argoviensis one can think that there is one single collection (Staunton s.n.) with the holotype in G and the isotype in C. However, Müller Argoviensis added 'i.e.', meaning a single form! (id est), this is the original specimen to the $\mathrm{C}$ sheet.

Moreover the Staunton collection cannot be the type of M. mollisimus, because there is no evidence that Geiseler ever saw it. It was given by Lambert to De Candolle in 1816, as was written on the label (for additional information see also Miller, 1970: 543).

Since the Crotonis Monographiam from Geiseler (1807) is based on material from Vahl at the Copenhagen Herbarium, by circumstantial evidence, the most likely speci- 
men to be the type is the Vahl specimen found in $\mathrm{C}$ as was actually said by Müller Argoviensis. Like Croizat (1938: 141) we doubt the Chinese origin of this specimen as no other one has come to our attention. The nearest occurrence could be Tu Phap in North Vietnam, but the provenances given by the collector d'Aleizette cannot always be trusted. The specimens cited by Gagnepain (1925: 357) and Poilane 1685 cited by Croizat as well, as far as seen belong to M. metcalfianus.

A letter by Croizat on July 14, 1938, that is after the publication of his paper (April $27,1938)$ suggests a possible Indonesian origin and this seems a good suggestion.

2. Croton ricinoides was described from India. The lectotype was collected by Lahaye, who never was in India (cf. Van Steenis-Kruseman, 1950: 307) but did collect in Malesia.

3. Mallotus metcalfianus Croizat can be easily confused with M. mollissimus, in particular because of the fruits. The main differences are found on the stellate indumentum: dark brownish, densely tomentose (light brown, dense to scattered, big, rarely densely tomentose in $M$. mollissimus); glandular hairs not very visible (visible glandular hairs in M. mollissimus); the presence of 2-6 basal extrafloral nectaries $(0-2(-4)$ in M. mollissimus) on the upper side of the blade; big buds and flowers (small buds and flowers in $M$. mollissimus); female flowers with connate sepals (connate at the base in M. mollissimus); ovary 3- or (4-)locular (ovary 3-locular in M. mollissimus); rough seeds (smooth seeds in $M$. mollissimus); fruits with thicker layer of indumentum on the spines.

Collections studied of M. metcalfianus:

Kwangsi: Sup-man-ta Shan (Liang 69716, syntype). Thailand: Nong Khai (Bunchuai 1826), Plao Thong (Niyomdham 4882). Vietnam: Tu Phap (Balansa 3320, syntype); Dam ha: Sai Wong Mo Shan (Tsang 30253), Lung Wan (Tsang 30032); Annam: La' Han (Poilane 1685), Mt Dani (J. \& M.S. Clemens 3616).

4. Mallotus paniculatus (Lam.) Müll. Arg.

Mallotus paniculatus (Lam.) Müll. Arg. (1865) 189; Backer \& Bakh.f. (1964) 483; Airy Shaw (1975) 166; (1980) 169; (1981) 327; (1982) 29; (1983) 37; Corner (1988) 307; P.I. Forst. (1999) 478, 496; Keßler (2002) 50; Welzen, Slik \& Bollendorff in Van Welzen et al. (2000) 103; W.J. Kress, DeFilipps, E. Farr \& Yin Yin Kyi (2003) 232. - Croton paniculatus Lam. (1786) 207; A. Juss. (1824) 33, comb. in Rottlera not made!. - Rottlera paniculata (Lam.) Blume (24 Jan.1826) 604; Spreng. (Jan.-Mar.1826) 877 (isonym). - Lectotype (Forster, 1999): Commerson s.n. (holo P, Herb. A. Juss. 16579 [IDC microfiche no. 6206]), Indonesia, Java.

Echinus trisulcus Lour. (1790) 633. - Mappa cochinchinensis Spreng. (1826) 878, nom. superfl. - Lasipania tricuspis Raf. (1838) 22, nom. superfl. - Type: Loureiro s.n. (holo BM? n.v.), Vietnam, Annam, Cây hón.

Mallotus cochinchinensis Lour. (1790) 635. - Trewia tricuspidata Willd. (1806) 835, nom. superfl. - [Mallotus chinensis Lour. ex Müll.Arg. (1866) 965, in syn. sphalm. pro cochinchinensis]. - Lectotype (selected here): Loureiro s.n. (BM [photo at BRI]), Vietnam, Annam.

Rottlera alba Roxb. [(1814) 73, nom. nud.] ex Jack (1820) 26; Roxb. (1832) 829, isonym. - Mallotus albus (Roxb.) Müll.Arg. (1865) 188, quoad basionym et Wall. 7818. - Lectotype (selected here): William Roxburgh fil. s.n. $\equiv$ Wallich Numer. List 7818 A (Hb. Roxb.!) (holo BR sh 849430 in fr., curiously the label says male, P, fide leaf fragment in A, Icon Ined. 1712; iso BR, CAL, K-W), Malaysia, P. Penang.

Croton appendiculatus Elmer (1908) 312. - Type: Elmer 9215 (holo PNH †; iso L, NY, US), Philippines, Luzon. 
Shrubs to small trees up to $15 \mathrm{~m}$ high, dbh up to $24 \mathrm{~cm}$, dioecious, rarely monoecious. Bole up to $4 \mathrm{~m}$ high; crown up to $4 \mathrm{~m}$ long; bark with much tannic acid, outer bark rough to finely fissured or pustular lenticellate, reddish brown with yellowish brown lenticels, up to $10 \mathrm{~mm}$ thick; inner bark and wood white. Indumentum tomentose to puberulent. Stipules triangular, $0.8-1.5$ by $0.4-0.7 \mathrm{~mm}$, caducous, margin entire, apex acute. Leaves: petiole $30-180$ by $0.5-2.5 \mathrm{~mm}$, greenish tawny; blade subpeltate for $1.5 \mathrm{~mm}$, broadly ovate to ovate, $4-23.5$ by $3-15 \mathrm{~cm}$, length/width ratio $0.8-2$, reddish brown when young, base rounded to cuneate, margin entire to (irregularly) dentate, sometimes 2-lobed at widest part of blade, sometimes hastate, longest lobes up to 30 $\mathrm{mm}$, upper surface dull dark green, basally with $0-2$ extrafloral nectaries, $0.8-5$ by $0.5-2.5 \mathrm{~mm}$, yellowish green, marginal nectaries $0-11$ per side, $2-4 \mathrm{~mm}$ from margin, $0.3-0.8$ by $0.2-0.8 \mathrm{~mm}$, lower surface light brownish grey to coppery, domatia absent, 3 -nerved, nerves $6-8$ per side, looping or ending in the margin. Inflorescences axillary or terminal, unisexual to rarely bisexual, axes greenish tawny, basally $2-4 \mathrm{~mm}$ thick; bracts triangular to narrowly triangular, $1.9-2.2$ by $0.3-0.4 \mathrm{~mm}$, bracteoles $0.4-1$ by $0.3-0.5 \mathrm{~mm}$, persistent, margin entire. Staminate inflorescences up to $45 \mathrm{~cm}$ long, side branches up to $28 \mathrm{~cm}$ long, with 3-7 flowers per node, nodes per branch up to 70 , hairy. Staminate flowers 3-5 mm diam.; pedicels 3-4 mm long; sepals 3 or 4 , elliptic, reflexed, $2.2-3$ by $1.2-1.8 \mathrm{~mm}$, pale yellow; stamens $40-65$, filaments $1.5-2$ $\mathrm{mm}$ long, white, anthers $0.2-0.3$ by $0.1-0.2 \mathrm{~mm}$, orange-yellow; pistillode present. Pistillate inflorescences panicles, occasionally racemes, up to $30 \mathrm{~cm}$ long, nodes up to 75 (per branch). Pistillate flowers 3-4 mm diam.; pedicels up to $1 \mathrm{~mm}$ long; calyx 3-5-lobed, connate on the base, 2-2.6 mm long, cream brown, lobes ovate, 1.5-2.2 by $0.7-1 \mathrm{~mm}$; ovary 3 -locular, $1.3-1.5$ by $1.7-2 \mathrm{~mm}$, cream brown, spines individually visible; style up to $1 \mathrm{~mm}$ long, yellow; stigmas $1.2-2 \mathrm{~mm}$ long, yellow; staminodes absent. Fruits $3-12$ by $5.5-14 \mathrm{~mm}$, greenish tawny, spines few, straight to curved, thick, hairy, up to $7 \mathrm{~mm}$ long, hairs not forming a continuous layer, not rubbing off; column $2.8-3.3$ by $1.8-2.2 \mathrm{~mm}$. Seeds globose, $2-3$ by $2-3$ by $2-2.5 \mathrm{~mm}$, smooth, black, shiny; hilum c. 1 by c. $1 \mathrm{~mm}$.

Note - The criteria used for the recognition of a variety are the slight differences in morphology which partly overlap or are otherwise not of importance for species delimitation and the absence of clear differences in their geographical distribution. Mallotus paniculatus and M.paniculatus var.formosanus slightly differ in their measurements, shape of the leaf margin, and the ending of the nerves (as can be seen in the descriptions), and are both found in Taiwan. Since these two taxa agree with the criteria mentioned above, we decided to maintain var. formosanus.

\section{KEY TO THE VARIETIES}

1a. Blade 4-23.5 cm long, nerves looping, margin entire to dentate, sometimes 2-lobed at widest part of blade, never hastate, base rounded to cuneate, basal extrafloral nectaries $1.8-5$ by $1-2.5 \mathrm{~mm}$. Fruits $5-12$ by $6-14 \mathrm{~mm}$, spines up to $7 \mathrm{~mm}$ long. - India to Taiwan, throughout Southeast Asia to East Australia and New Guinea 4a. var. paniculatus

b. Blade $5.5-13 \mathrm{~cm}$ long, nerves ending in the margin, margin irregularly dentate, always 2-lobed at widest part of blade, sometimes hastate, base cuneate, basal 
extrafloral nectaries $0.8-1$ by $0.5-0.8 \mathrm{~mm}$. Fruits $3-3.5$ by $5.5-6.2 \mathrm{~mm}$, spines up to $3 \mathrm{~mm}$ long. - Taiwan ............... 4b. var. formosanus

a. var. paniculatus - Fig. 4; Map 4

For synonymy see under the species.

Leaves: petiole $30-180$ by $0.4-0.7 \mathrm{~mm}$; blade $4-23.5$ by $3-15 \mathrm{~cm}$, length/width ratio 1.2-2, base rounded to cuneate, margin entire to dentate, sometimes 2-lobed, never hastate, nerves looping, extrafloral nectaries basally $1.8-5$ by $1-2.5 \mathrm{~mm}$, marginal nectaries $0.7-0.8$ by $0.7-0.8 \mathrm{~mm}$. Fruits $5-12$ by $6-14 \mathrm{~mm}$, spines up to $7 \mathrm{~mm}$ long; column $3-3.3$ by $2-2.2 \mathrm{~mm}$. Seeds $2.5-3$ by $2.5-3$ by $2-2.5 \mathrm{~mm}$.

Distribution - From India to Taiwan, throughout Southeast Asia and Malesia to East Australia and New Guinea.

Habitat \& Ecology - Locally common in deciduous and evergreen forest, mostly in open, often very disturbed or burned places, in ravines and on dry sites like plateaus, ridges and slopes, in thickets, and along rivers and roadsides; on a large variety of soil types, like basalt, clay, granite, laterite, limestone, loam, rocky, sandy, ultrabasic, and volcanic. Altitude: sea level up to $1800 \mathrm{~m}$. Flowering and fruiting the whole year through. It grows fast and was observed to be visited by ants and birds eating the fruits.

Uses - The roots are boiled and drunk after child birth. The bark is used for construction, making strings, and it is used by the Loi (in China) to make a coarse cloth from which men's jackets were made. The leaves are used against fever. The indumentum of the young leaves is applied on the penis after circumcision. The wood is used for paper pulp, wallboard, light construction, and as firewood.

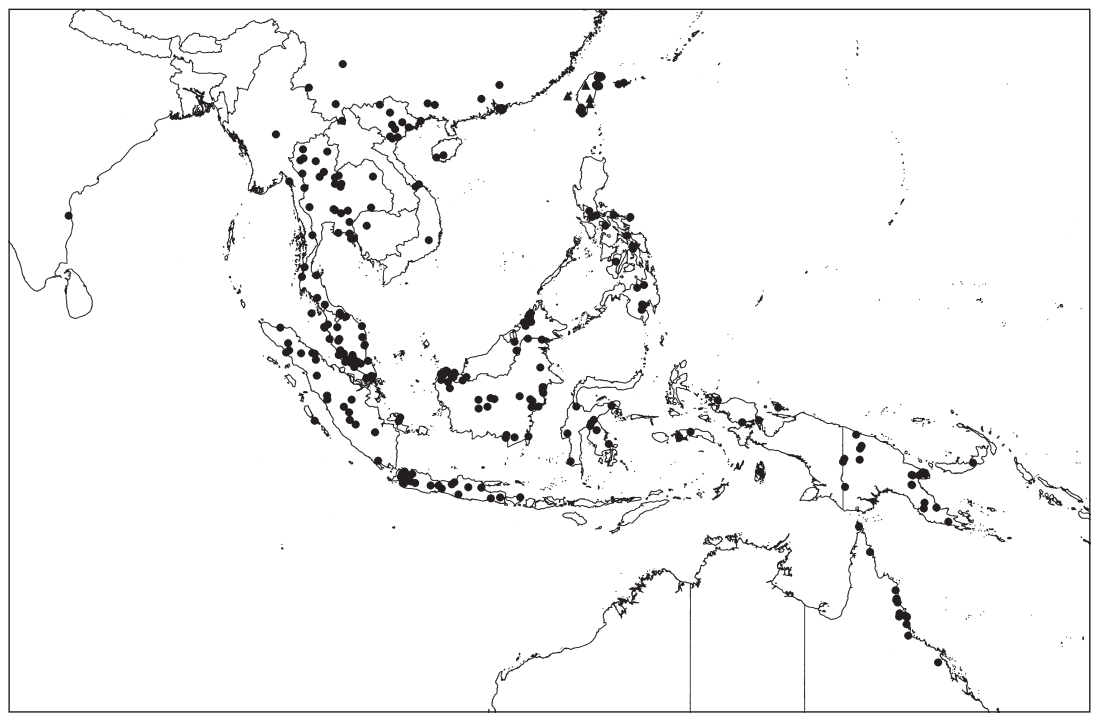

Map 4. Distribution of Mallotus paniculatus (Lam.) Müll.Arg. var. paniculatus (@), and M. paniculatus (Lam.) Müll.Arg. var. formosanus (Hayata) Hurus. (A). 


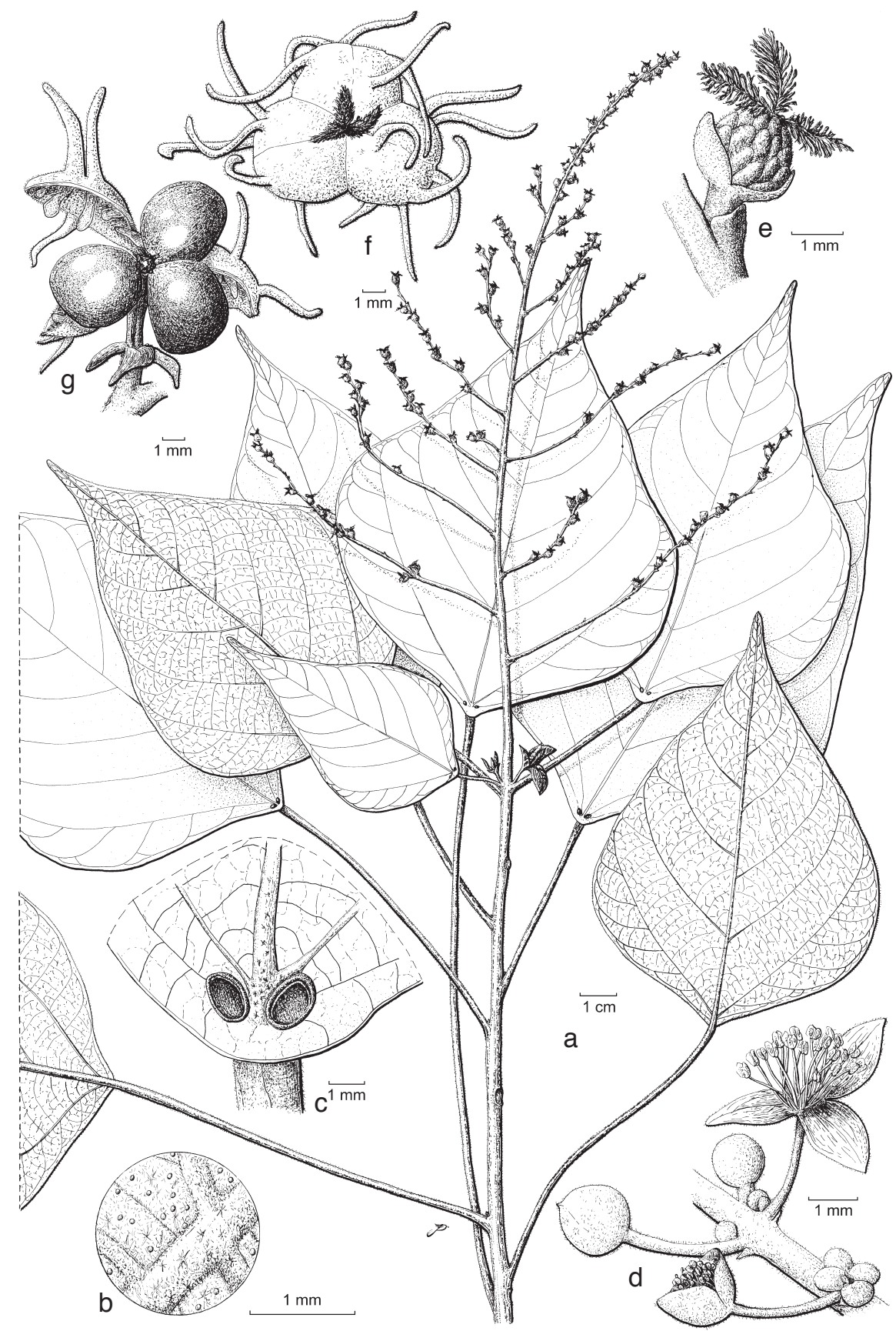

Fig. 4. Mallotus paniculatus (Lam.) Müll. Arg. a. Habit with pistillate inflorescence; b. detail of leaf lower surface with glandular hairs; $c$. base of leaf upper surface with extrafloral nectaries; $d$. staminate flower and bud; e. pistillate flower; f. fruit; g. dehisced fruit showing seeds and apex of column (a-c, e: Furuse 1432, K; d: Wilkie 94134, L; f: Van Balgooy 3632, L; g: Hu \& But 21908, L). 
Vernacular names - China: Pak pui shu, paak foi neung shue. Thailand: Khi non, khi tao, lang khao, saet, salat, salat pang, sa-ri nok, sati nam, sati ton, soi dao, sti num, sti ton, tak gua (Thai); turn-in-the-wind (English). Cambodia: Krabas pua phom. Singapore: Balak adap. Malaya: balek angin (Kechil, Semelai); bue-ra kae puteh (Malay Peninsula); balek (Sakai); balik angina, musapal itam, poko balek angina. Sabah: Balabakan (Bandukam, Bajau); parak balik (Dusun Kwijau); dauh (Dusun Putatan); entupak (Iban); sirindien (Land Dayak); balek angin. Sarawak: dagoh (Dusun); berlekut (Kelabit); sirindien jamis (Land Dayak); balek angin (Malay); balik angina. Indonesia (Kalimantan): Butaq (Tunjung Benua); bayur, keminting boeroeng, waring kangin laki. Philippines: Hinlaumong-puti (Bisáya); anaplán (Bukídnon); lamai. Sumatra: Balik angin (Alas); saringkut (Karo); bali-bali angina, balik angina, balik-balik angin silai, boedi, kajoe lappisi, kajoe si balik angina, kajoe si djoekkat, kajoe si tarak balanggingngan, lilouw. Java: Tjalik angin (Sundanese), ki tjoelih angin perak, ki-manggong, ki-talikangin, walung. Sulawesi: Kajukuo (Uma), Kapilah. Japan (Ryukyu): Urajiro-akamegashiwa. Papua (Irian Jaya): Kanibor (Kutubu); lengle (Miwaute); gayanbangemba (Waskuk); bangiam, kolamalama. Papua New Guinea: Poekwa (Hattam). Partly after Salvosa (1963) and Smitinand (2001).

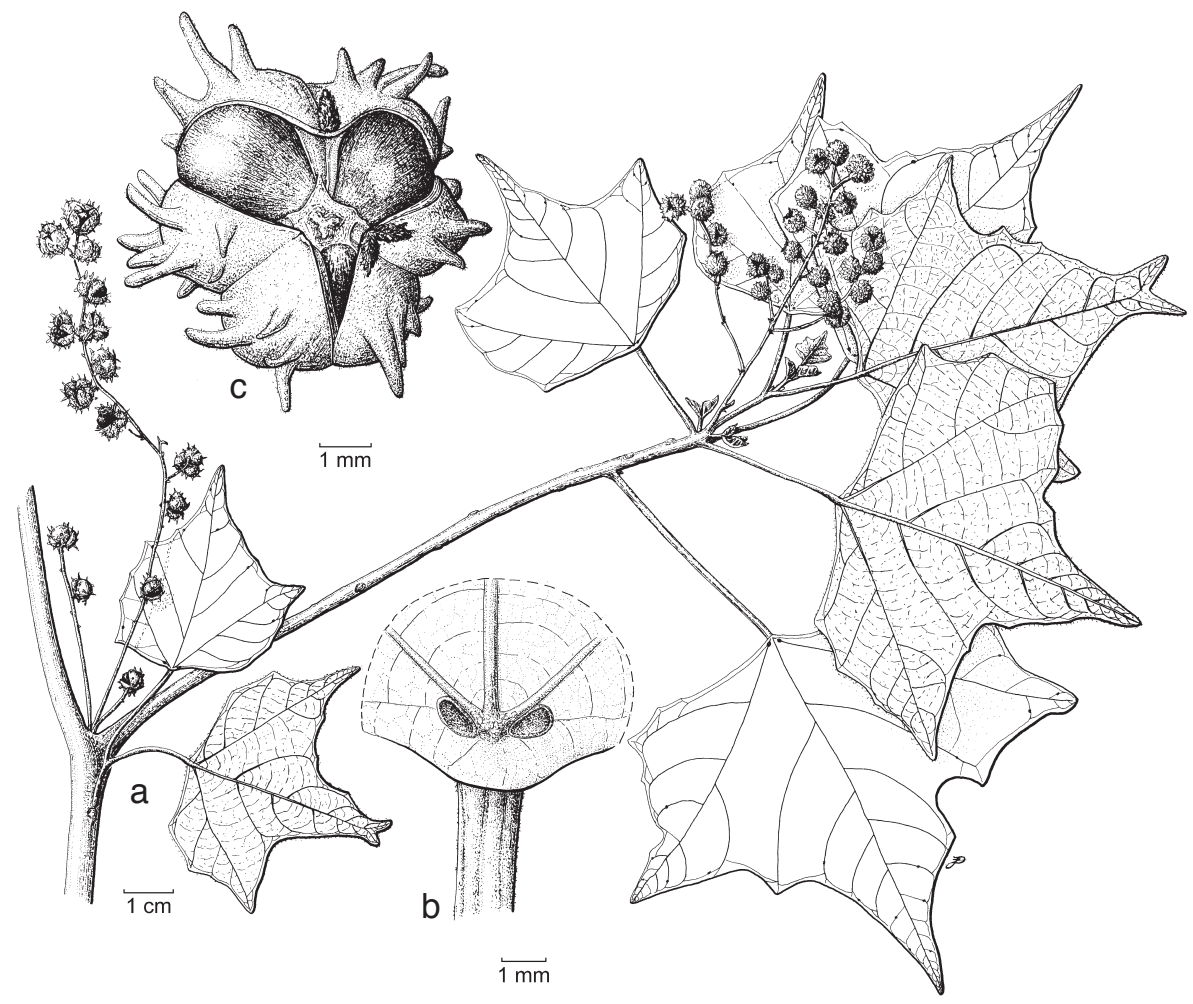

Fig. 5. Mallotus paniculatus (Lam.) Müll.Arg. var. formosanus (Hayata) Hurus. a. Habit with infructescence; b. base of leaf upper surface with extrafloral nectaries; c. dehisced fruit showing seeds and apex of column (all: Liu 97, A). 
b. var. formosanus (Hayata) Hurus. - Fig. 5; Map 4

Mallotus paniculatus (Lam.) Müll.Arg. var. formosanus (Hayata) Hurus. (1954) 307. - Mallotus formosanus Hayata (1911) 269. - Lectotype (Kurosawa \& Shimizu, 2000): Unknown s.n. (TI), Taiwan, Randai-san, Fukô.

Leaves: petiole $35-100$ by $0.5-1 \mathrm{~mm}$; blade $5.5-13$ by $4-13 \mathrm{~cm}$, length/width ratio $0.8-1.2$, base cuneate, margin irregularly dentate, always 2-lobed, sometimes hastate, nerves ending in the margin, extrafloral nectaries basally $0.8-1$ by $0.5-0.8 \mathrm{~mm}$, marginal nectaries $0.3-0.4$ by $0.2-0.3 \mathrm{~mm}$. Fruits $3-3.5$ by $5.5-6.2 \mathrm{~mm}$ (including spines), spines up to $3 \mathrm{~mm}$ long; column $2.8-3$ by $1.8-2 \mathrm{~mm}$. Seeds $2-2.5$ by $2-2.5$ by $2-2.2 \mathrm{~mm}$.

Distribution - Taiwan.

Habitat \& Ecology - Remnant of secondary evergreen forest, along hillsides and road margins. Altitude: sea level up to $500 \mathrm{~m}$. Flowering: June to August; fruiting: December to January.

\section{ACKNOWLEDGEMENTS}

The directors of the following institutes are thanked for lending their material: A, AAU, B, BM, BP, BR, BRI, C, CAL, CANB, CGE, DBN, DD, DPU, DS, E, F, FH, FI, G, GJO, H, HAL, HK, IBSC, JE, K, KEP, KIEL, L, LD, LE, LIV, M, MA, MANCH, MEL, MICH, MO, NSW, NY, OXF, P, PDA, PH, PR, S, SAN, SBT, SING, SYS, TCD, TI, TU, U, UC, US, W, WRSL. Special thanks are due to J.F. Veldkamp for his valuable help concerning nomenclatural problems; J. Porck, A. Walsmit Sachs, and J. van Os for the drawings; B. Vrijbloed and G. Thijsse for the administration of the collections, L. Frankova and D.N.F. Kiehl for help with the literature; Ding Hou for help with the Chinese translations; J.M. de Wolf, B.J. van Heuven for technical support; J.B. Mols and K. Kulju for their comments on the manuscript. This study was financially supported by the Alberta Mennega Stichting, Stichting Hugo de Vries, Stichting Leids Universiteits Fonds (LUF), and the Society for the Advancement of Research in the Tropics (TREUB).

\section{REFERENCES}

Airy Shaw, H.K. 1968. Malesian and other Asiatic Euphorbiaceae. Kew Bull. 21: 379-400.

Airy Shaw, H.K. 1972. The Euphorbiaceae of Siam. Kew Bull. 26: 292-308.

Airy Shaw, H.K. 1975. The Euphorbiaceae of Borneo. Kew Bull., Addit. Ser. 4: 160-174.

Airy Shaw, H.K. 1980. The Euphorbiaceae of New Guinea. Kew Bull., Addit. Ser. 8: 162-172.

Airy Shaw, H.K. 1981. The Euphorbiaceae of Sumatra. Kew Bull. 36: 323-330.

Airy Shaw, H.K. 1982. The Euphorbiaceae of Central Malesia (Celebes, Moluccas, Lesser Sunda Is.). Kew Bull. 37: 28-30.

Airy Shaw, H.K. 1983. An alphabetical enumeration of the Euphorbiaceae of the Philippine islands. Royal Botanic Gardens Publication, Kew.

Backer, C. A. \& R.C. Bakhuizen van den Brink Jr. 1964. Flora of Java 1. Noordhoff, Groningen.

Baillon, H.E. 1858. Étude générale du groupe des Euphorbiacées. Masson, Paris.

Baillon, H.E. 1866. Species Euphorbiacearum Euphorbiacées Australiennes. Adansonia 6: 313317.

Blanco, F.M. 1837. Flora de Filipinas. Sto. Thomas, Manila.

Blanco, F.M. 1845. Flora de Filipinas (ed. 2). Sanchez, Manila.

Blume, C.L. 1826. Bijdragen tot de flora van Nederlandsch-Indië 11: 485-730. Lands Drukkerij, Batavia.

Bollendorff, S.M., P.C. van Welzen \& J.W.F. Slik. 2000. A taxonomic revision of Mallotus section Polyadenii (Euphorbiaceae). Blumea 45: 319-340. 
Corner, E.J.H. 1988. Wayside Trees Malaysia. Euphorbiaceae, Mallotus. ed. 3, 1: 304-308. The Malayan Nature Society, Kuala Lumpur.

Croizat, L.C.M. 1938. Notes on Chinese Euphorbiaceae. J. Arnold Arbor. 19: 134-148.

De Jussieu, A.H.L. 1824. De Euphorbiacearum generibus. Didot Jr., Paris.

De Lamarck, J.B.A.P. 1786. Encyclopédie méthodique. Botanique. 2. Paris.

De Loureiro, J. 1790. Flora Cochinchinensis 1. J. de Loureiro, Ulyssipone (Lisboa).

Elmer, A.D.E. 1908. A century of new plants. Leafl. Philipp. Bot. 1: 272-314.

Fedde, F.K.G. 1911. Vermischte neue Diagnosen. Repert. Spec. Nov. Regni Veg. 10: 144.

Forman, L.L. 1997. Notes concerning the typification of William Roxburgh's species of Phanerogams. Kew Bull. 52: 513-534.

Forster, P.I. 1999. A taxonomic revision of Mallotus Lour. (Euphorbiaceae) in Australia. Austrobaileya 5: 457-497.

Gagnepain, F. 1925. Euphorbiaceae. In: M.H. Lecomte, Fl. l'Indo-Chine 5: 229-673. Masson \& Cie, Paris.

Geiseler, E.F. 1807. Crotonis monographiam, speciminis loco inauguralis, ut doctoris medici gradum in alma fridericiana adipiscatur. Grunert, Halle.

Greuter, W., J. McNeill, R. Barrie, H.-M. Burdet, V. Demoulin, T.S. Filguerias, D.H. Nicolson, P.C. Silva, J.E. Skog, P. Trehane, N.J. Turland \& D.L. Hawksworth (editors \& compilers). 1999. International Code of Botanical Nomenclature (St Louis Code). Regnum Veg. 138.

Hasskarl, J.C. 1844. Catalogus plantarum in horto botanico bogoriensi cultarum alter. Lands Drukkerij, Batavia.

Hayata, B. 1911. Materials for a Flora of Formosa. J. Coll. Sci. Imp. Univ. Tokyo 30: 269-271.

Hurusawa, I. 1954. Eine nochmalige Durchsicht des herkömmlichen Systems der Euphorbiaceen im weiteren Sinne. J. Fac. Sci. Univ. Tokyo, sect. 3, Bot. 6, 6: 303-309.

Hwang, S.M. 1985. New material of Mallotus L. from China. Acta Phytotax. Sin. 23: 293-301.

Jack, W. 1820. Description of Malayan plants. 1. Sumatra Mission Press, Bencoolen.

Keßler, P. J.A. 2002. Checklist of woody plants of Sulawesi, Indonesia. Blumea, Suppl. 14: 49-50.

Kiu, H.S. 2003. Noteworthy taxa from China (continued II). In: H.T. Chang \& H.S. Kiu, Guihaia 23: 97-101.

Kress, W.J., R. A. DeFilipps, E. Farr \& D. Yin Yin Kyi. 2003. A checklist of the trees, shrubs, herbs, and climbers of Myanmar (rev. ed. 4). Department of Systematic Biology-Botany, National Museum of Natural History, Washington, DC.

Kurosawa, T. \& A. Shimizu. 2000. Catalogue of the type specimens preserved in the herbarium, Department of Botany, The University Museum, The University of Tokyo. Part 7. Euphorbiaceae. The University Museum, The University of Tokyo, Material Reports No. 41: 37.

Lanjouw, J., S.H. Mamay, R. McVaugh, W. Robyns, R.C. Rollins, R. Ross, J. Rousseau, G.M. Schulze, A.C. Smith, R. de Vilmorin \& F. A. Stafleu. 1966. International code of botanical nomenclature (Edinburgh Code). Regnum Veg. 40.

Lauener, L.A. 1983. Catalogue of the names published by Hector Léveillé: XVI. Notes Roy. Bot. Gard. Edinburgh 40: 475-505.

Léveillé, A. A.H. 1911a. Decades plantarum novarum. LIV-LVIII. Repert. Spec. Nov. Regni Veg. 9: 321-330.

Léveillé, A.A.H. 1911b. Decades plantarum novarum. LIX-LXX. Repert. Spec. Nov. Regni Veg. 9: 441-463.

Léveillé, A.A.H. 1914. Flore du Kouy-Tchéouchéou. Léveillé, Le Mans.

Merrill, E.D. 1912. Notes on Philippine Euphorbiaceae. Philipp. J. Sci., Bot. 7: 379-410.

Merrill, E.D. 1918. Species Blancoanae. Euphorbiaceae: 221-223. Bureau of Printing, Manila.

Merrill, E.D. 1920. Notes on Philippine Euphorbiaceae, III. Philipp. J. Sci. 16: 559-561.

Metcalf, F.P. 1931. Botanical notes on Fukien and Southeast China, IV ${ }^{1}, V^{2}$. Lingnan Sci. J. 10: 483-489.

Metcalf, F.P. 1941. New species of Mallotus. J. Arnold Arbor. 22: 204-208.

Miller, H. S. 1970. The herbarium of Aylmer Bourke Lambert. Taxon 19: 489-656.

Miquel, F. A.W. 1859. Flora van Nederlandsch Indië 1, 2. Fleischer. Leipzig.

Miquel, F.A.W. 1860. Flora van Nederlandsch Indië, Eerste Bijvoegsel. Fleischer, Leipzig. 
Moritzi, A. 1846. Systematisches Verzeichniss der von H. Zollinger in der Jahren 1842-1844 auf Java gesammelten Pflanzen. Moritzi, Solothurn.

Müller Argoviensis, J. 1865. Euphorbiaceae. Linnaea 34: 184-197.

Müller Argoviensis, J. 1866. Euphorbiaceae tribus Acalypheae. In: A. de Candolle, Prodromus Systematis Naturalis Regni Vegetabilis 15, 2: 956-983. Masson \& Fili, Paris.

Pax, F. \& K. Hoffmann. 1914. Euphorbiaceae-Acalyphae-Mercurialinae. In: A. Engler, Pflanzenreich IV.147.vii: 145-212, 394-397. Engelmann, Leipzig.

Persoon, C.H. 1807. Synopsis plantarum 2, 2. Cramer, Paris; Cotta, Tübingen.

Radcliffe-Smith, A. 2001. Genera Euphorbiacearum. Royal Botanic Gardens, Kew.

Rafinesque, C.S. 1838. Sylva telluriana. Rafinesque, Philadelphia.

Reichenbach, H.G. \& H. Zollinger. 1857. Ueber die Rottlera-Arten. Linnaea 28: 299-332.

Roxburgh, W. 1814. Hortus bengalensis. Mission Press, Serampore.

Roxburgh, W. 1832. Flora Indica 3. Thacker \& Co., Calcutta; Parbury, Allen \& Co., London.

Salvosa, F.M. 1963. Lexicon of Philippine trees. Forest Products Research Institute, Laguna.

Sierra, S.E.C., P.C. van Welzen \& J.W.F. Slik. 2005. A taxonomic revision of Mallotus section Philippinenses (former section Rottlera - Euphorbiaceae) in Malesia and Thailand. Blumea 50: 221-248.

Slik, J.W.F. \& P.C. van Welzen. 2001a. A taxonomic revision of Mallotus sections Hancea and Stylanthus (Euphorbiaceae). Blumea 46: 3-66.

Slik, J.W.F. \& P.C. van Welzen. 2001b. A phylogeny of Mallotus (Euphorbiaceae) based on morphology: Indications for a pioneer origin of Macaranga. Syst. Bot. 26: 786-796.

Smitinand, T. 2001. Thai plant names. Revised edition. Royal Forest Department, Bangkok.

Sprengel, C. 1826. Systema vegetabilium 3. Librariae Dieterichianae, Göttingen.

Steudel, E.T. 1840. Nomenclator botanicus ed. 2, 2. Stuttgart, Tübingen.

Van Steenis-Kruseman, M.J. 1950. Cyclopaedia of collectors. In: C.G.G.J. van Steenis (ed.), Flora Malesiana 1, 1: 307. Noordhoff-Kolff, Djakarta.

Van Welzen, P.C., R.M.A.P. Haegens, J.W.F. Slik, S.M. Bollendorff, S. Dressler \& H.-J. Esser. 2000. Checklist of the genera of Thai Euphorbiaceae. Thai Forest Bull., Bot. 28: 93-111.

Von Mueller, F.J.H. 1864. Fragmenta phytographiae Australiae 4. Joannis Ferres, Melbourne.

Wallich, N. 1847. A numerical list of dried specimens of plants in the East India Company's museum. Wallich, London.

Webster, G.L. 1994. Synopsis of the genera and suprageneric taxa of Euphorbiaceae. Ann. Missouri Bot. Gard. 81: 33-144.

Willdenow, C.L. 1806. Species Plantarum, ed. 4, 2. Nauk, Berlin.

\section{IDENTIFICATION LIST}

The numbers behind the collector numbers refer to the following taxa:

$$
\begin{aligned}
1 & =\text { Mallotus barbatus Müll.Arg. } \\
2 & =\text { Mallotus macrostachys (Miq.) Müll.Arg. } \\
3 & =\text { Mallotus mollissimus (Geiseler) Airy Shaw } \\
4 \mathrm{a} & =\text { Mallotus paniculatus (Lam.) Müll.Arg. var. paniculatus } \\
4 \mathrm{~b} & =\text { Mallotus paniculatus (Lam.) Müll.Arg. var. formosanus (Hayata) Hurus. }
\end{aligned}
$$

A series $387: 3 ; 422: 4 \mathrm{a} ; 597: 2 ; 750: 2 ; 924: 2 ; 1213: 3 ; 1259: 3 ; 1460: 3 ; 1585: 3 ; 1655: 4 \mathrm{a} ; 1726: 3$; 1807: 2 ; 2001: 3 ; 2093: 3 ; 2200: 2; 2388: 3; 2526: 2; 2728: 2; 2785: 3; 3210: 3; 3269: 3 - Achariya 7: 4a - Achmad 50: 4a; 343: 4a - Aet 215: 3 - Ahern's collector 34: 3 - Ahmad 782: 4a; 1195: 2 - Alston 14720: 4a; 16159: 3 - Alvins 35: 4a; 839: 4a; 1152: 4a; 1776: 4a; 1860: 4a - Ambriansyah AA 1159: 4a; AA 1606: 4a; AA 2451: 4a - Ambriansyah \& Arbainsyah AA 1720: 2 - Ambriansyah \& Arifin AA1696: 4a; W 78: 2; W138: 4a - Ambriansyah et al. AA 1187: 4a; AA 1190: 4a; AA 1628: 3 - Amdjah 264a: 2 - Amir 23: 4a - Anang 236: 3; 550: 3; 552: 3 - Ando et al. 9a: 4a; 583: 2 - Angian 10319: 3 - ANU series 1546: 3; 1681: 3; 1735: 4a - Apostol 2401: 4a; 7170: 3 - Arbainsyah et al. AA 1849: 4a; AA 1934: 4a - Argent \& 
Iqbar 9972: 4a - Argent \& Saridan 9331: 2 - Argent \& Wilkie 9434: 4a - Argent et al. 107671: 2 - Arifin \& Arbainsyah AA 1036: 3; AA 1043: 3; AA 1044: 3; AA 1753: 2 - Arifin et al. AA 1072: 3; AA 1151: 4a; AA 1708: 3 - Averyanov et al. 1220: 4a; 1812: 4a; 4036: 4a.

Backer 6702: 4a; 7861: 3; 7978: 3; 9980: 4a; 17057: 4a; 22878: 3; 30433: 3; 30601: 3 - Baker 3693: 4a - Bakhuizen van den Brink Sr. 137a: 4a; 505: 4a; 3981: 4a - Bakhuizen van den Brink Jr. 1624: 3; 3498: 3 - Balajadia 3062: 2 - Balansa 721: 1; 726: 4a; 727: 4a - Bartholomew 7796: 4b - Bartlett 7552: 4a; 13549: 3; 13668: 3 - Bateson 23a: 3; 23b: 3 - Bayak 2132: 3 - bb series 22: 1; 2123: 3; 2132: 4a; 4146: 4a; 4154: 4a; 4985: 4a; 5924: 4a; 6107: 4a; 6609: 4a; 14128: 3; 15595: 4a; 24977: 4a; 28281: 3; 29843: 3 - Bean 3933: 4a; 16165: 3 - Beccari PS 523: 4a; 1074: 4a; 2156: 2; 2258: 4a - Beijing Youth Exp. 1048: 4a; 1088: 1 - Bergman 170: 4a - Bernstein 166: 3 - Beumée 72: 4a; 4450: 3; 5658: 3; 5660: 4a - Bidin 15653: 4a — Bloembergen 4412: 3; 4495: 3; 4498: 3 - Bodinier 388: 4a; 784: 4a; 848: 4a; 891: 4a Boerlage 180: 4a - Bogor Botanical Garden IX.A. 80: 4a; IX.C.53: 4a; IX.C.53a: 4a; IX.E. 38: 4a - Bois 114: 1; 194: 1 - Boufford et al. 25255: 4a - Bradtke 340: 3 - Brass 1022: 3; 1961 : 4a; 2188: 4a; 3000: 3; 5297: 3; 5616: 3; 7462: 4a; 7774: 4a; 23908: 3; 24344: 3; 24410: 3; 25982: 4a; 26016: 3; 27418: 4a; 27547: 4a; 28629: 3; 32119: 4a; 32644: 3 - Britton 389: 3; 494: 3 - Brooke 8145: 4a; 10258: 3; 10370: 4a - BRUN series 17170: 2 - BS series 21: 3; 87: 4a; 121: $3 ; 125: 3 ; 153$ : 4a; 158: 3; 180: 4a; 238: 3; 255: 3; 350: 3; 513: 4a; 925: 4a; 1101: 3; 1137: 4a; 1385: 4a; 1409: 3; 1650: 3; 1671: 4a; 1703: 2; 2567: 2; 2695: 4a; 3128: 3; 5895: 3; 8232: 3; 9417: $3 ; 12336: 3 ; 12690: 3 ; 12692: 3 ; 13328: 3 ; 14468: 3 ; 15613: 3 ; 15808: 3 ; 17577: 3 ; 17601$ : 3; 20863: 3; 20877: 3; 23310: 4a; 26143: 3; 27481: 3; 28206: 3; 30882: 3; 30883: 3; 31850: 3 ; 32474: 3 ; 33726: 4a; 33896: 3; 34362: 3; 36820: 3 ; 37992: 3; 38766: 3; 39164: 4a; 39373: 3 ; 41366: 3 ; 42472: 3 ; 46200: 3; 49875: 3; 75552: 4a; 76089: 4a; 77127: 3; 77430: 3; 77731: 3; 77868: $3 ; 78631: 3 ; 85125: 3$ - BSIP series $2156: 3 ; 3495: 3 ; 6076: 3 ; 6627: 3 ; 9181: 3 ; 10513$ : 3; 10538: 3 ; 10664: 3; 12279: 3; 13417: 3; 13595: 3; 14161: 3; 14301: 3; 14389: 3; 15365: 3; 15716: 3; 16470: 3; 17495: 3 - Bünnemeijer 1782: 4a; 2280: 4a; 7800: 4a - Bunpheng 50: 4a; 621: 4a; 837: 1 - Burkill 6415: 4a - Burkill \& Shah 1065: 2 - Burley 79: 3 - Burley et al. 2003: 2; 2006: 4a; 2040: 4a - Burn-Murdoch 49: 2 - Burut Ho 1904: 3; $2991: 3$ - Büsgen 19: 4a - Buwalda 2760: 4a; 2840: 3 - BW series 2361: 3; 3831: 3; 4544: 3; 4706: 3; 6361: 3; 9484: 3 ; 12586: $4 \mathrm{a} ; 13944: 3 ; 14885: 3$.

Cantley 20: 4; 116: 4a; 2605: 4a; 2717: 4a - Carr 11056: 3; 11071:3; 11468: 3; 11725: 3; 13480: 4a; 14835: 4a; 14836: 4a; 15334: 4a; 15616: 3; 16029: 4a - Carrick \& Enoch 314: 4a - Castro \& Melegrito 1393: 3 - Cavalerie 3666: 1; 4382: 1 - Cel series V292: 3 - Chan 128: 4a - H.O. Chan CCC 3010: 4a; 8208: 4a - Charoenphol et al. 4430: 4a - Cheesman 61: 3 - Chen 91369: 1 - Chew 1094: 2 - Chew et al. 2618: 3 - Chiao \& Fan 22: 1; 646: 1 - Chin 3420: 3 - Ching 5699: 1; 7655: 4a; 7762: 4a; 7912: 4a - Chintayungkun T8535: 2 - Chow 6129: 1; 6244: 1; 6296: 1; 78075: 4a - Chow \& Wan 80064: 1 - Chua et al. 493: 4a - Chuang 3035: 4a - Chun 6342: 1; 6400: 1; 6605: 4a - Chun \& Tso 43773: 4a; 43791: 4a - Church et al. 537: 2; 1234: 4a - Clarke 527: 4a - Clason C 32: 3 - J. Clemens \& M.S. Clemens 1011: 4a; 1545: 4a; 3615: 4a; 3618: 1; 20488: 4a; 22484: 4a; 28640: 4a; 29166: 4a; 29609: 3; 29764: 3; 50567: 4a - M.S. Clemens 842: 3; 6512: 4a; 6572: 4a; 8374: 3; 8728: 3; 9617: 3; 10148: 3; 10485: 4a; 10590: 3; 20176: 2; 21240: 2; 40690: 3; 50567: 4a - Co 3246: 3 - Collins 491: 4a; 560: 4a; 2362: 2 - Congdon 61: 4a; 232: 2 - Congdon \& Hamilton 232: 2 - Conn \& Vinas 1666: 4a - Coode 5376: 3 - Coode et al. 6360: 2; 6980: 2 - Copral Hassan 1: 4a - Craven \& Schodde 895: 3; 1421: 4a - Crome 240: 4a - Cubitt 874: 4a - Cuming 454: 3; 542: 3; 2313: 4a - Cuong 3: 4a; 95: 1; 439: 4a - Curtis 43: 4a; 1437: 4a; 1983: 1.

Danimihardja 2221: 3; 2286: 4a - Darbyshire 302: 4a; 700: 3 - Darbyshire \& Hoogland 7934: 3 - Davies \& Unam 97003: 4a; 97008: 4a; 97009: 2 - Davies et al. 99059: 3; 99195: 3; 981203: 2 - Dayao Shan Team 11003: 1 - De Jong 671: 4a - De Malahilde 49: 1 - De Vogel 791: 3; 5039: 3; 5920: 3 - De Vogel \& Vermeulen 6453: 3; 6680: 3 - De Voogd 1179: 3; 1191: 4a — De Wilde \& De Wilde-Duyfjes 12684: 4a - Dee 665: 4a - Derry 9: 4a; 972: 4a - Dissing et al. 1819: 3 - Dorgelo 100: 3 - Du 102: 1 - Duaneh 5: 3 - Ducloux 2163: 1.

Ebalo 106: 3; 872: 3 - Eberhardt 4306: 1 - Elbert 2693: 3; 2819: 3; 2912: 3; 2943: 3; 2996: 3; 3248: 3 ; 3416: 3; 3442: 3; 3442a: 3; 3702: 3; 4250: 3; 4283: 3 - Elmer 7109: 3; 8086: 3; 8157: 
3; 9215: 4a; 9792: 3; 10146: 3; 11735: 3; 11926: 4a; 14331: 3; 14549: 4a; 14922: 4a; 15181: 4a; 17612: 3; 17894: 3; 22176: 3 - Endert 80: 4a; 1606: 4a - Enggoh 10143: 2 - Esquirol 120: 1 - Esser 9838: 1; 9878: 4a; 98124: 1; 98131: 4a; 98133: 1; 98205: 4a; 98224: 4a - Evangelista 1115: 3 - Evrard 1899: 4a; 1900: 4a - Eyma 3409: 4a.

Fallen et al. 347: 3 - Fang 680: 1; 2291: 1; 12483: 1; 16986: 1; 17065: 1 - Faurie 196: 4a - FB series $2846: 3 ; 2968: 3 ; 3592: 3 ; 3631: 3 ; 3709: 3 ; 6588: 3 ; 11220: 3 ; 15146: 3 ; 16506: 3 ; 16984$ : 3; 17465: 4a; 18279: 3; 18713: 3; 22158: 3; 28381: 3 - Fell \& Butcher 2610: 4a - Fell \& Stanton 4058: 4a - Feng 11442: 1; 12157: 4a; 12206: 1; 13424: 4a; 14031: 4a - FMS series 1308: 2; 9024: 2; 10197: 2; 13088: 2; 28170: 2 - Forbes 196: 4a; 208: 4a; 2699: 4a; 2699A: 4a - Forman 254: 3 - Forsten 388: 3 - P.I. Forster 9526: 3; 14323: 4a; 14724: 4a - P.I. Forster \& Booth $24252: 4 \mathrm{a}$ - P.I. Forster \& Sharpe 12442: 3 - P.I. Forster et al. 13676: 3 - Fosberg 38064: 4a - Fox 10789: 1 - FPRI series 432: 3 - Franck 1131: 4a - Frodin \& Ismawi 2013: 4a - Fukuoka T-63685: 4a - Fukuoka \& Ito T-34529: 4a - Furet 122: 4a - Furuse 1432: 4a; 2242: $4 \mathrm{a} ; 4677: 4 \mathrm{a}$.

Gai 35: 4 - Galathea Expeditionen 1680: 1 - Garrett 760: 1; 1321: 1 - Gebo 470: 3 - Geesink et al. 5613: 4a; 5653: 1; 6882: 1 - Gentry \& La Frankie 66967: 2 - Gianno 237: 4a - Gibbs 2660: 3; 2721: 3 - Goklin 1970: 3 - Goodenough 5040: 4a - Goreja 33: 3 - Goverse \& Adriansyah B 429: 4a; B 430: 4a - Griffith 132: 4a; 329: 4a; — Griffith KD 4756: 4a; 4761: 1 - Groff 5774: 4a - Guard 9024: 2.

Haenke 2486: 4a - Hallier 92: 4a; 805: 2; 897: 4a; 1348: 2; 2552: 4a; 2872: 2; 4011: 3; 4078: 3 - Hamdi 2119: 4a; 2318: 1; 13256: 4a - Hance 1491: 4a - Handel-Mazzetti 10364: 1 - Haniff 159: 1 - Haniff \& Nur 3809: 2 - Hansen 44: 2; 857: 2 - Hardial 215: 4a; 599: 4a - Hardial \& Munir 9: 4a; 681: 4a - Hardial \& Samsuri 215: 4a; 685: 4a - Hardial \& Sidek 401: 2 - Hartley 9989: 4a; 10942: 3; 11380: 4a; 13073: 3 - Hatusima 23099: 4a - Haviland 850: 2 - Haviland \& Hose 2099B: 4a; 2099D: 4a; 2099E: 4a; 2099G: 4a; 3661B: 4a; 3661E: 4a; 3661F: 4a; 3661G: 4a; 7744A: 4a; 8879: 4a - Hellwig 186: 3 - Henrey 63: 4a; 834: 4a; 962: 4a; 8718: 4a; 12365 : 4a - Henry 810: 1; $1598: 4 a ; 1598$ (NY mixed): 4a; 1598 (A, NY mixed): 4b; 9525: 1; 9525a: 1; 9525b: 1 - Herre 316: 4a - Hertel 23246: 4a - Hervey 5039: 4a - Hirano \& Hotta 265: 2 - Hochreutiner 2558: 4a; 2769: 4a - Höft 3385: 3 - Högel 608: 3; 610: 3 - Holman 39: 3 - Holttum 9303: 2 - Hong Kong Herb. 5143: 4a - Hoogland 3784: 3; 4563: 3 - Hoogland \& Craven 10173: 4a; 10418: 4a - Hoogland \& Macdonald 3460: 3 - Hose 138: 2; 434: 2; 461: 2 - Hosseus 623: 1; 624: 1 - Hotta 13416: 2 - How 71095: 4a - Hsu 4116: 4a - Hu 6194: 4a; 6325: 4a; 8368: 4a; 12360A: 4a; 12728: 4a - Hu \& But 21908: 4a; 22668: 4a - Huc 592: 2 - Hullet 138: 4a; 252: 4a - Hume 7528: 4a - Hyland 3098: 3; 3100: 3; 3394: 4a; 6267: 3; 7746: 4a; 7788: $3 ; 8621: 3 ; 9061: 3$.

Iboet 317a: 3; 386: 3; 456: 4a; 475: 3 - Ibrahim 3384: 3 - Idjan \& Mochtar 336: 3 - Indrapong 71: 2 - Irvine 96: 3; 1362: 4a - Iwatsuki et al. S-1712: 4a; S-14636: 4a; T-10881: 1.

Jacobs 4844: 4a; 8272: 4a - Jarvie \& Ruskandi 5026: 2; 5030: 4a - Jensen 91: 3 - Jeswiet 1441: 2 - Jobson 1181: 4a - Johansson et al. 527: 3 - Jones 3865: 4a.

Kajewski 1871: 3 - Kamis 4766: 3 - Kandilis 6249: 4a; 7114: 3 - Kanehira 4071: 3 - Kanehira \& Hatusima 14140: 3 - Kanis 1294: 3 - Kao 227: 4a; 6156: 4b; 6577: 4a; 7253: 4b - Karta 60: 4a; 79:3 - Kartawinata 925: 3 - Kaudern 64: 3 - Kawakami 290: 4a - Keith 65: 3; 9897: 3; 10726: 3 - Keng 47: 2; 1361: 4b - Keng \& Kao 1307: 4a - KEP series 26991: 4a; 37576: 4a; 59601: 2; 60909: 4a; 71617: 4a; 94660: 2; 98638: 4a; 98658: 2; 98671: 2; 98689: 4a - KEP FRI series 232: 4a; 262: 4a; 884: 4a; 1706: 2; 1797: 1; 1846: 4a; 3834: 4a; 4624: 2; 5719: 2; 7131: 2 ; 8635: 2 ; 11108: 2 ; 11149: 2; 11517: 2 ; 11839: 2 ; 11923: 2; 13052: 2; 13351: 2 ; 13414 : 4a; 13630: 2; 13676: 4; 14203: 4a; 14510: 2; 15773: 2; 17123: 4a; 17356: 4a; 17386: 4a; 17888: 4a; 27524: 2 - Kerr 553: 4a; 806: 4a; 1433: 4a; 2765: 4a; 4964: 1; 6664: 4a; 9855: 4a; 11679: 2; 17918: 4a; 18636: 2; 19088: 4a - Keßler et al. 1298: 2; 1534: 2; 2243: 2; B 81: 4a; B 119: 3; B 120: 3; B 270: 4a; PK 283: 4a; PK 789: 3; PK 794: 3; PK 796: 3; PK 825: 4a; PK 875: 4a; PK 1054: 4a; PK 1089: 4a; PK 1102: 3; PK 1164: 4a; PK 1244: 4a; PK 1302: 3; PK 1303: 3; PK 1350: 3; PK 1351: 3; PK 1435: 4a; PK 1601: 3; PK 1816: 3; PK 1848: 4a; PK 1934: 3; PK 1989: 3; PK 2071: 4a; PK 2076: 4a; PK 2356: 4a; PK 2383: 4a; PK 2982: 3; PK 3149: 3; PK 3169: 3 - Khng et al. 716: 4a; 984: 4a - King's collector 250: 4a; 251: 4a; 315: 2; 778: 2; 779: 2; 1823: 
1; 2265: 4a; 2303: 2; 2313: 2; 2367: 2; 2496: 2; 4666: 2; 4933: 4a; 8721: 4a; 10452: 4a; 10992: 2 - Kingdon Ward 8926: 1 - Kjellberg 481: 4a; 2254: 4a; 2861: 4a - KL series 8: 4a; 2348: 2; 2399: 4a; 2525: 4a; 2926: 2 - Ko 55581: 4a - Kodiok A 1807: 2 - Kohyama \& Noma K 3793: 4a - Køie 1819: 3 - Kollmann 717: 4a - Kondo 8449: 4a - Kool 540: 3 - Koorders 2386: 3; 2453: 3; 2501: 4a; 2502: 4a; 2503: 4a; 2506: 4a; 2508: 4a; 2509: 4a; 2511: 4a; 2512: 4a; 2513: 4a; 2514: 4a; 2515: 4a; 2516: 4a; 2517: 4a; 2518: 4a; 2570: 3; 2573: 3; 2574: 3; 2575: 3; 2576: 3; 2580: 4a; 2581: 3; 2583: 3; 2584: 3; 2585: 3; 11258: 4a; 11959: 4a; 12759: 3; 13093: 3; 13575: 3; 13576: 3; 14440: 3; 14442: 3; 16907: 3; 16908: 3; 20205: 3; 20504: 3; 22063: 3; 22660: 3 ; 22731: 3 ; 23667: 3; 23739: 4a; 24200: 4a; 24833: 3; 24985: 3; 25696: 4a; 25729: 4a; 26161: 3; 26653: 3; 27390: 3; 27734: 4a; 28927: 3; 29229: 4a; 29941: 3; 30027: 3; 30542: 3; 30973: 3; 30977: 4a; 32925: 3 - Kooy 838: 3 - Kornassi 742: 3 - Kostermans 8: 2; 2799: 3; 18199: 3; 21262: 3; 21820: 4a - Kostermans \& Soegeng 899: 4a - Kostermans \& Van Woerden 162: 3 - Kostermans \& Wirawan 255: 3 - Koyama et al. T-30133: 4a; T-31567: 4a; T-34059: 2 - Kramadibrata 137: 2 - Krukoff 4173: 2 - Kschua et al. 211: 4a - Kudo \& Suzuki 15953: 4a - Kui 67020: 4a - Kuntze 3811: 1; 4787: 4a; 4876: 4a; 6075: 4a - Kuo 5536: 4a.

Lace 5982: 4a - LAE series 56786: 3; 62204: 3; 62222: 4a; 70352: 3; 83045: 3 - LaFrankie 2393: 2; 3155: 2 - Lakshnakara 1013: 1 - Lam 2463: 3; 2645: 3 - Lambinon 8785: 4a; 87/361: 3 - Lamont 645: 4a - K. Larsen 70825: 4a - K. Larsen et al. 280: 4a; 665: 1; 1834: 1; 9432: 4a; 31545: 1; 32090: 1; 41222: 4a; 41640: 2; 45467: 4a; 46196: 4a - Latiff et al. ALM1598: 1 - Latupeirissa 94384: 2 - Lau 2522: 4a; 3124: 4a; 4868: 4a; 5328: 4a; 20208: 4a; 20240: 1; 27615: 4a; 27859: 4a; 28036: 4a; 28681: 1 - Laumonier 5612: 2 - Lauterbach 6181: 4a - Lecomte \& Finet 29: 1; 1248: 4a - Ledermann 6698: 4a - Lee 3011: 1 - Leeuwenberg \& Rudjiman 13107: 4a; 13457: 4a - Lei 128: 4a; 211: 4a; 821: 4a - Leighton 382: 4a - Lewandowsky 59: 3 - Li 15: 1; 355: 1; 883: 4a; 1593: 1; 1703: 1; 1784: 4a; 7707: 1; 200543: 1 - Liang 771: 1; 62336: 4a; 63153: 4a; 64224: 4a; 69830: 4a; 95311: 4a - Liao 1580: 4b; 10599: 4b - Libo Team 8180114: 1 - Lin 250: 4a; 874: 4a - Liu 24: 4a; 97: 4b; 1297: 1; 14285: 1 - Liu et al. 304: 4a - Lobb 297: 1 - Loher 4820: 3; 4821: 3; 4822: 3; 4823: 3; 6870: 3 - Lörzing 915: 4a; 5150: 4a; 5152: 4a; 11340: 2; 12716: 4a; 12717: 4a.

Madulid \& Majaducon 8411: 3 - Mahamud 2777: 4a - Maingay KD 1381: 2; 1382: 4a - Majaducon 8606: 3 - Maung Ba Pe 12920: 4a - Maxwell 71-713: 4a; 72-546: 4a; 73-526: 4a; 73-588: 4a; 84-209: 2; 84-340: 4a; 84-564: 2; 85-1121: 2; 87-938: 4a; 87-1644: 4a; 89-578: 1; 90-1268: 4a; 92-526: 1; 93-134: 4a; 96-46: 4a; 96-764: 1; 97-456: 1; 97-494: 1; 98-411: 1; 99-237: 1; 99-243: 1; 01-555: 4a - McClure 876: 4a; 8208: 4a; 20077: 4a - McDonald \& Ismail 4914: 4a - McDonald \& Sunaryo 4381: 3 - McKee 1627: 3 - Meijer 3997: 4a; 5877: 4a; 9395: 3; 10112: 3; 10931: 3; 11053: 4a - MEL series 232425: 3; 232426: 3; 232427: 3; 232428: 3; 232429: 3 - Merrill 664: 3; 904: 3; 1183: 3; 1910: 3; 1911: 3; 2382: 3; 3399: 3; 3400: 3; 5308: 1 - Merrill Species Blancoanae 474: 3 - Metzner 97: 3 - Middleton et al. 1122: 1; 1538: 4a - Mohamud 2777: 4a - Monod de Froideville 737: 4a - Morci 1083.1: 4a - Motley 529: 4a; 530: 2 - Moulton 6737: 2 - Mousset 303: 4a - Murata et al. B-572: 2; B-3028: 2; T-16462: 4a; T-42526: 4a; T-50047: 4a.

Nanakorn 757: 2 - Nangkat NN74: 2 - Native Collector 180:4a - Nedi \& Idjan 318:4a - Nemoto \& Hoshi 24818: 4a - Newman et al. 1019: 1 - NGF series 139: 3; 1638: 3; 2530: 3; 5456: 3; 6418: 3 ; 9808: 3 ; 14058: 4a; 14421: 4a; 14482: 3 ; 14498: 3 ; 14992: 3 ; 16744: $3 ; 16748: 4 a ; 20761$ : 4a; 20767: 3; 21908: 3; 23068: 3; 24027: 3; 24075: 3; 26026: 3; 27960: 3; 33006: 4a; 33895: 3; 37272: 4a; 40532: 3; 41106: 3; 42790: 4a; 44474: 3; 48110: 4a - Nielsen 40: 2 - Nimanong \& Phusomsaeng 256: 4a - Nitrasirirak 204: 2 - Niyomdham 4933: 1 - Niyomdham et al. 337: 4a; 1872: 4a - Noerkas 355: 3 - Nooteboom 1052: 3; 1352: 3; 1614: 2; 1615: 3; 5761: 3 - Novotny et al. 11: 3 - Nur 3421: 4a; 34056: 4a.

Ogata 10188: 4a; 10266b: 4a; 11047: 3 - Ohashi et al. 13250: 4a; 13494: 4a; 13856: 4a; 24019: 4a - Oldham 477: 4a.

Panatkool 40: 1; 41: 1 - Panoff 210: 4a - Parnell et al. 95047: 1; 95144: 1 - Passier Pogor 36: 4a - Peng 9039: 4a; 11959: 4a; 12244: 4a; 13532: 4a; 14026: 4a - Pételot 802: 4a; 1236: 4a; 1677: 4a; 2218: 1; 2291: 4a; 2350: 4a - Peters \& Susanto 1140: 4a - Phengklai 451: 4a; 602: 4a - Phengklai et al. 3838: 4a - Phusomsaeng \& Pinnin 314: 2 - Pierre 6265: 1 - Pillai 22: 
4a - Pleyte 189: $3 ; 368: 3 ; 1063: 4 a-$ PNH series $36: 3 ; 73: 3 ; 74: 3 ; 164: 3 ; 957: 4 a ; 1018: 4 a$; 1613: 3 ; 1664: 3 ; 1697: 3; 1963: 3; 1964: 3; 2926: 3; 3242: 3; 4044: 3; 8303: 3; 9163: 3; 9534 : 3; 9796: 4a; 11282: 3 ; 11362: 3; 17543: 3; 17788: 3 ; 17818: $3 ; 17910: 3 ; 17940: 3 ; 18345: 3$; 19719: $3 ; 19840: 3 ; 21803: 3 ; 33450: 3 ; 33941: 3 ; 34138: 3 ; 34433: 3 ; 35383: 3 ; 36026: 3 ; 37273$ : 3; 37724: 3; 38881: 3; 39087: 3; 39639: 3; 41875: 4a; 42696: 3; 72844: 3; 78303: 3; 79957: 3; 80795: 3; 87732: 3 - Poilane 931: 1; 2185: 4a; 8185: 4a; 9063: 4a; 13488: 4a; 13588: 1; 19918: 4a - Pooma et al. 2612: 1 - Posthumus 567: $4 \mathrm{a}$ - PPI series 217: 3; 388: 3; 486: 3; 1363: 4a; 1487: $3 ; 1552: 3 ; 2022: 3 ; 2182: 4 a ; 2480: 4 a ; 2567: 3 ; 2752: 3 ; 2776: 3 ; 3697: 4 a ; 4011: 3 ; 4069$ : 3; 4810: 3; 5147: 3; 5608: 3; 7064: 3; 7470: 4a; 7519: 3; 7935: 3; 8345: 3; 8494: 4a; 9085: 3; 9186: 3; 9307: 4a; 9971: 3; 10415: 3; 11215: 3; 11847: 3; 11947: 3; 12577: 3; 12935: 3; 13114: 3; 14667: $3 ; 14927: 3 ; 15072: 3 ; 15329: 3 ; 15360: 3 ; 15586: 3 ; 15621: 3 ; 15695: 3 ; 18047: 3 ; 18071$ : 3; 18362: 3 ; 18857: 3 ; 19963: 3; 20332: 3; 21151: 3 ; 21670: 3; 22359: 3; 23015: 3; 23849: 3; 24413: $3 ; 24706: 3 ; 25153: 3 ; 25246: 3 ; 25323: 3 ; 26049: 3 ; 27191: 3 ; 27413: 3 ; 27584: 3 ; 29183$ : $3 ; 37052: 3 ; 37309: 3 ; 38276: 3 ; 38835: 3$ - Prapat 4: 2 - Prapto \& Misgiantoro 12: 4a - Pratt 128: 1 - Prawiroatmodjo \& Maskuri 1203: 4a; 1266: 3; 1270: 3; 1479: 3; 1535: 3 - Puasa 2741: 3; 10113: 3 - Puasa \& Angian 3886: 3 - Pulle 1116: 4a; 1185: 4a - Pullen 3600: 3; 5490: 4a - Pulsford \& Floyd 109: 3; 110: 3 - Purseglove \& Shah 4832: 4a - Purseglove 4653: 4a - Put 686: 4a; 806: 4a; 1369: 1; 1618: 1; 2738: 4a.

Qin 368: 1; 866: 1; 867: 1 - Qin et al. 895486: 1.

Rachmat 197: 3; 280: 3; 731: 3; 851: 3 - Rahayu 277: 2 - Rahman 6754: 3 - Rahmat si Boeea (= Rahmat si Toroes) 167: 2; 334: 2; 1611: 4a; 1815: 4a; 1909: 4a; 2060: 4a; 2279: 4a; 2628: 4a; 2721: 4a; 2911: 4a; 3142: 4a; 3469: 4a; 3693: 4a; 3973: 1; 4179: 1; 4182: 4a; 4340: 2; 4550: 4a; 4966: 2; 5007: 4a; 5145: 2; 5624: 4a; 5807: 4a; 6520: 4a; 7895: 4a; 8936: 4a; 9397: 4a - Ramlanto 16: 4a - Ramlanto \& Fanani 645: 3 - Ramos 1409: 3 - Rau 490: 3 - Read 13531: 3 - Rensch-Maier 635: 3 - Research Institute 6: 1 - RFD series 3759: 4a; 4883: 1; 11217: 1; 12498: 4a; 27601: 1; 57392: 2 - Ridley 20: 4a; 416: 4a; 1337: 4a; 2344: 2; 3445: 2; 3448: 2; 3627A: 2; 6987: 1; 12594: 2; 13712: 2; 14512: 1; 14513: 2 - Riswan et al. B123: 2 - Robbins 2126: 3 - Robinson 1723: 4a - Rosalina 17: 4a - RSNB series 1394: 3; 2618: 3; 2825: 4a — RSS series 2652: 3; 2918: 3 - Rudder 3684: 4a - Rutten 746: 3; 2177: 4a.

S series 343: 4a; 12845: 4a; 19227: 2; 24748: 2; 29845: 4a; 32702: 4a; 33205: 2; 35104: 4a; 35451: 4a; 35630: 2; 36082: 2; 36417: 4a; 36734: 4a; 36735: 2; 38405: 2; 42448: 4a; 42532: 4a; 42912: 2; 43788: 2; 45325: 2; 46208: 2; 46301: 2; 48626: 4a; 49585: 4a; 49586: 4a; 51711: 4a; 53063: 4a; 54299: 2; 56329: 2; 56695: 2; 57345: 4a; 57523: 4a; 57525: 4a; 57529: 4a; 57531: 2; 57532: 4a; 57542: 4a; 59325: 3; 59927: 4a; 59952: 4a; 59953: 4a; 61624: 4a; 62277: 4a. - Saibeh 43: 3 - Saimoendt 27: 4a; 28: 4a - Sambuling 709:3 - Samsuri et al. 348: 4a - SAN series 18707: 4a; 19029: 2 ; 24889: 2 ; 29481: 2 ; 29519: 2 ; 31496: 3; 31714: 3; 32632: 2 ; 32825: 2 ; 32863: 2 ; 34948: $2 ; 35073: 3 ; 35567: 2 ; 38267: 3 ; 41002: 3 ; 50633: 2 ; 51372: 3 ; 55903: 3 ; 56038: 3 ; 56226$ : 3; 58916: 2; 60452: 4a; 64209: 3; 64366: 3; 67226: 2; 67549: 2; 68026: 2; 68048: 3; 68128: 2; 68807: $2 ; 69466: 2 ; 70334: 2 ; 70670: 3 ; 77253: 3 ; 79395: 3 ; 79826: 3 ; 80218: 2 ; 80414: 2 ; 80746$ : 3; 81134: 2; 82329: 3; 82428: 3; 82687: 2; 83759: 2; 83924: 2; 84215: 2; 84252: 2; 84307: 2; 84483: $3 ; 84658: 3 ; 84774: 3 ; 86022: 2 ; 86601: 3 ; 89288: 3 ; 89711: 2 ; 91357: 2 ; 91436: 3 ; 95366$ : 3; 99280: 4a; 99316: 3 ; 99505: 3; 99673: 3; 100034: 3; 100598: 2 ; 101446: $3 ; 101832: 3 ; 102724$ : 3; 102938: 3 ; 103040: 3 ; 103369: 3; 103447: 3; 105603: 4a; 106816: 3; 107078: 3; 108107: 3; 108115: 2 ; 109359: 4a; 109468: $3 ; 109785: 3 ; 110052: 3 ; 111499: 3 ; 112925: 2 ; 113055: 2 ; 113602$ : 2; 114195: 3 ; 114276: 3; 114346: 4a; 114718: 3 ; 114920: 3 ; 115425: 3 ; 115464: 3 ; 115565: 3 ; 115675: 3 ; 115924: 3 ; 116142: 3 ; 116221: $4 \mathrm{a} ; 116318: 3 ; 116406: 3 ; 116536: 3 ; 116681: 3 ; 117162$ : 3 ; 117165: 3 ; 117363: 3 ; 117818: 3; 118212: 3 ; 118900: 3 ; 119164: 3 ; 120060: 2 ; 120563: 4a; 121464: 3 ; $122186: 2 ; 123146: 3 ; 123185: 3 ; 123288: 3 ; 123354: 3 ; 123754: 2 ; 125282: 2 ; 126361$ : 3; 127948: 2 ; 128761: 3 ; 131277: 3; 131525: 3; 132227: 3; 134249: 3; 135001: 3; 136893: 4a; 136894: 2; 137094: 2; 139191: 3; 139741: 2 - Sands 6182: 3; 6241: 3 - Sangkhachand 139: 4a; 213: 2; 390: 2; 559: 4a; 1389: 2; 1499: 4a - Sangkhachand \& Nimanong 1296: 2 - Santos 4769: 3; 5302: 3 - Sarip 171: 3 - Satake 229: 4a - Sawyer 225: 3; 226: 4a - Sayers 154: 4a - Schiffner 2147: 3 - Schlechter 17589: 3; 18883: 3 - Schmutz 18: 3; 156a: 3; 709: 3 - Schodde 2213: 4a; 2464: 3 - Schodde \& Craven 4707: 3; 4804a: 4a - Schomburgk 52: 
2 - Scortechini 21: 1; 477: 1 - SF series 4262: 1; 9227: 4a; 11865: 2; 12571: 4a; 13524: 2; 13530: 4a; 14634: 4a; 15506: 4a; 17305: 4a; 17608: 4a; 17637: 4a; 19591: 2; 20512: 4a; 22481: 2; 23650: 4a; 24712: 2; 32818: 4a; 33060: 1; 33335: 4a; 33467: 1; 36056: 2; 37765: 4a; 39090: 4a; 40441: 1; 40498: 2; 40741: 4a; 40761: 4a - Shah 36: 4a; 78: 2 - Shah \& Ali 3054: 4a - Shea 23747: 4a - Shen 1898: 4a; 1899: 4a - Shikano 10305: 4b - Shimizu T-10374: 4a; T-10573: 4a; T-11282: 4a; T-22383: 4a - Shimizu \& Boufford M-11720: 4a - Shimizu et al. M-14041: 2; T-12982: 4a; T-26377: 2; T-27167: 2 - Shukor 33: 2 - Sibil 31: 3 - Sidek bin Kiah 632: 4a - Sidisunthorn \& Gar 2769: 4a - Sidiyasa 298: 4a; 639: 4a; 1214: 2; 1282: 2 - Sidiyasa \& Arifin 1999: 2; 2061: 3; 2083: 3 - Sidiyasa \& Didi 1859: 4a — Sidiyasa et al. 1309: 3; 3644: 3 - Sinclair 9986: 3 - Sinclair \& Edaño 9514: 3; 9711: 3; 9712: 3 - Sinclair \& Kiah 40441: 1 - Sino-American Expedition to Yunnan 225: 1 - Sino-American Guizhou Botanical Expedition 32: 1; 1642: 1 - Sirirugsa 337: 4a - Slik W 1054: 4a; W 1055: 4a; W 1058: 2 - C. Smith 26: 4a; 76: 3; 3818: 3; 11219: 3 - Smitinand 11713: 2 - Soejarto 39: 3 - Soejarto \& Madulid 6198: 3 - Soejarto \& Reynoso 6282: 3 - Soejarto et al. 6467: 3; 8264: 3; 9701: 1; 9728: 4a; 10996: 4a; 11502: 1 - Soenarko 310: 3 - Soepadmo \& Mahmud 9066: 2 - Soetisna 16: 4a - Soh M36: 2 - Song 113: 1 - Squires 317: 1 - Stern 2125: 4a; 2127: 3 - Steward \& Cheo 356: 1 - Stocker 669: 3 - Stone 5766: 4a; 5767: 4a; 10760: 4a - Stone \& Soh 6408: 2 - Stone \& Weber 15947: 4a - Streimann 8494: 3 - Strugnell 10410: 1; 13197: 2 - Suleiman 2206: 3 - Sun \& Chang 805: 1 - Susanto \& Peters 1182: 4a - Susuki 11664: 4a - Symington 24475: 1; 25589: 1; 37967: 1 - Szemian 22: 3 .

Ta 842: 1 - Taam 4: 1; 1592: 4a; 1869: 4a - Tadong 21: 3 - Tagawa et al. T-10525: 4a - Taha 2571: 4a - Tahir 802: 3 - Takeuchi 4614: 3; 6859: 4a; 6940: 4a; 6975: 3; 15700: 4a; 15960: 4a; 16010: 4a - Tan \& Shah 4: 4a - Tanaka 5496: 4a - Tanaka \& Shimada 13420: 4a - Tandom 2915: 4a; 4120: 3; 4797: 3 - Tang \& Sidek 28: 4a; 829: 4a - Tao 475: 1 - Tateishi et al. 16765: 4a; 21283: 4a - Taylor 2200: 3 - Teng 90815: 1 - Teruya 911: 2; 2319: 4a - Teruya et al. 1622: 4a - Teijsmann HB 1914: 4a; HB 3245: 2; HB 3376: 2; HB 5071: 4a; HB 11022: 2; HB 11024: 4a; HB 14157: 3 - TFB series 592: 2; 638: 2; 780: 4a; 781: 4a; 907: 4a; 1243: 4a — Thomas 157: 2 - Thomas et al. 77892: 1 - Thorel 740: 4a - Tillich 1778: 4a — Ting \& Chen 312: 1; 547: 1 - Ting \& Shih 807: 4a - Tsai 60406: 1; 60590: 1; 60794: 1; 60818: 4a; 60900: 1; 61045: 1; 61487: 4a; 61583: 4a; 61631: 4a; 62043: 1 - Tsang 248: 4a; 16559: 4a; 22132: 1; 23810: 1; 23812: 1; 24194: 4a; 25796: 4a; 26023: 4a; 26853: 4a; 26896: 4a; 26998: 4a; 27371: 4a; 27527: 4a; 29558: 1; 29569: 4a; 29812: 1; 30187: 1; 30199: 1; 30225: 1; 30496: 4a; 30544: 1 - Tsiang 1131: 1 ; $2734: 1 ; 5308: 1 ; 5766: 1 ; 6995: 1 ; 9301: 1$ - Tsu 21239: 4a - Tsugaru 5595: 4a - Turner 211: 4a - Tzeng $2301: 4 a$.

UNESCO \& Kostermans 34: 3 - University of San Carlos 22: 3; 839: 3; 883: 3.

Vachell 258: 4a - Valera 8840: 3 -Van Balgooy 3515: 4a; 3632: 4a; 3875: 4a; 4759: 3; 4833: 3; 6908: 3 - Van Balgooy \& Keßler 5902: 2 - Van Beusekom \& Phengkhlai 895: 4a - Van Beusekom et al. 3372: 4a; 4775: 1; 4805: 4a - Van Borssum Waalkes 1891: 4a - Van de Bult 476: 4a - Van der Veen 1: 3 - Van der Werff et al. 17215: 1 - Van Kregten 12: 4a; 87: 3 - Van Ooststroom 12593: 4a - Van Royen 3233: 3; 4080: 4a - Van Steenis 1222: 4a; 2764: 4a; 3758: 3 - Van Valkenburg 381: 4a; 1208: 2 - Vanoverbergh 735: 3 - Vanpruk 262: 1; 733: 4a - Vaughan 575: 1 - Veldkamp 8774a: 4a; 8774b: 4a - Verheijen 598: 3; 599: 3; 4022: 3 — Vesterdal 12-S: 1; 146: 4a - Vidal, J.E. 320: 3; 579: 3; 579d: 3; 579e: 3; 579f: 3; 5767: 4a — Vidal y Soler 580: 3; 582: 3; 584: 3; 1670: 3; 1764: 3 .

Wagner 6628: 4a - Walker 83: 4a - Walker et al. 6534: 4a - Wallich 7818A: 4a; 7818B: 4a; 7818C (K mixed): 4a; 7818C?: 4a; 7818D: 4a; 7818D parte (K mixed): 4a; 7818E: 4a; 7820 parte (K mixed): 2; 7822A: 1; 7822B: 1; 7822C: 1 - Wang 35: 1; 69: 1; 158: 4a; 23140: 1; 33207: 4a; 33504: 4a; 34027: 4a; 35086: 4a; 35335: 4a; 36348: 4a; 37041: 1; 41085: 1; 73900: 4a; 75186: 4a; 75449: 1; 75502: 4a; 75535: 1; 75683: 4a; 75763: 4a; 76370: 1; 77781: 4a; 78008: 4a; 78533: 4a; 78637: 4a; 79155: 4a; 80363: 4a; 80716: 4a; 81067: 4a - Warburg 9950: 4a; 9955: 4a; 9958: 4a - Wardi 67: 4a - Waterhouse 104: 3; 146: 3; 230: 3; 304: 3; 350: 3 - Wawra 214: 4a — Webb \& Tracey 5672: 4a - Webster \& Hildreth 15059: 3; 15167: 4a; 15258: 3 - Webster \& Hyland 18888: 3 - Webster \& Tracey 18960: 3 - Wen 990624: 1 - Wenzel 407: 3; 408: 3; 420: 3; 1102: 4a; 1273: 3; 1755: 3; 3363: 3; 2003-18: 4a - Werner 81: 4a - White 510: 4a; 
11744: 4a - Whitford 711: 3 - Whitmore \& Sidiyasa 3369: 3 - Whitmore \& Sutisna TCW 3222: 2 - Widjaja 623a: 3; 691: 3 - Widjaja \& Hamzah 3104: 3 - Wilford 79: 4a - Wilkie 94134: 4a - Wilkie et al. 50: 4a - Wilson 11049: 4a; 11113: 4a - Winckel 1444: 4a; 1826: 4a - Winit 289: 1; 1151: 4a; 1441: 4a - Winkler 1755: 4a; 2536: 2; 2611: 4a - Wong 57: 3; 1649:

2 - Worthington 12345: 4a; 13145: 2; 13164: 4a - Wray 567: 1 - Wright 437: 4a.

Yamazaki 2928: 4a - Yates 1122: 1; 1647: 4a; 2354: 4a; 2662: 2 - Yusuf \& Wahyono 67: 4a.

Zainudin 5484: $4 \mathrm{a}$ - Zainudin et al. 1632: 3 - Zhang 9712062: 4a - Zhong 82434: 1 - Zollinger 140: 3; 319: 3; 468: 3; 695: 3; 801: 4a; 831: 4a; 963: 4a - Zwickey 15: 3.

\section{INDEX TO NAMES}

The numbers behind the names refer to the numbered species in this revision. Accepted names are in roman type; synonyms in italics.

Adelia barbata Blanco 3

bernardia auct. 3

Adisa zippelii Steud. 3

Adisca zippelii Blume 3

Chrozophora mollissima (Geiseler) A. Juss. ex Spreng. 3

Croton appendiculatus Elmer 4a mollissimus Geiseler 3

paniculatus Lam. 4a

ricinoides Pers. 3

Echinus Lour. [p. 250]

mollissimus (Geiseler) Baill. 3

trisulcus Lour. 4a

Lasipania tricuspis Raf. 4a

Mallotus Lour.

sect. Echinus Pax \& K. Hoffm. [p. 250]

sect. Eumallotus Müll.Arg. [p. 250]

sect. Mallotus Airy Shaw [p. 250]

sect. Melanolepis auct. [p. 250]

albus (Roxb.) Müll.Arg. 4a

albus auct. 2

barbatus Müll.Arg. 1

var. congestus F.P. Metcalf 1

var. hubeiensis S.M. Hwang 1

var. pedicellaris Croizat 1

var. wui H.S. Kiu 1

barbatus (Wall.) Müll.Arg. var. croizatianus (F.P. Metcalf)

S.M. Hwang 1

barbatus auct. 2, 3

chinensis Lour. ex Müll.Arg 4a

cochinchinensis Lour. $4 \mathrm{a}$

confusus Merr. 3

\author{
(Mallotus) \\ croizatianus F.P. Metcalf 1 \\ esquirolii H. Lév. 1 \\ formosanus Hayata 4b \\ insignis Müll.Arg. 2 \\ leveilleanus Fedde 1 \\ leveillei Fedde ex H. Lév. 1 \\ lotingensis F.P. Metcalf 1 \\ luchenensis F.P. Metcalf 1 \\ macrostachyus (Miq.) Müll.Arg. 2 \\ mollissimus (Geiseler) Airy Shaw 3 \\ paniculatus (Lam.) Müll.Arg. 4 \\ var. formosanus (Hayata) Hurus. 4b \\ var. paniculatus $4 \mathrm{a}$ \\ pycnostachys F. Muell. 3 \\ ricinoides (Pers.) Müll.Arg. 3 \\ zippelii F. Muell. 3 \\ Mappa cochinchinensis Spreng. 4a \\ zippelii Zoll. \& Moritzi ex Moritzi 3 \\ sp.: Moritzi 3 \\ Rottlera Roxb. ex Willd. \\ sect. Eurottlera auct. [p. 250] \\ sect. Trelotra Baill. [p. 250] \\ alba Roxb. 4a \\ barbata Wall. 1 \\ macrostachya Miq. 2 \\ paniculata (Lam.) Blume 4a \\ peltata auct. 3 \\ ricinoides (Pers.) A. Juss. 3 \\ zippelii Hassk. 3 \\ zippelii Zoll. \& Moritzi \\ var. minor Rchb.f. \& Zoll. 3 \\ Trewia tricuspidata Willd. 4a
}

